\title{
BIBLIOGRAFÍA DE RAFAEL LAPESA
}

\author{
Preparada por FCO. JAVIER SATORRE GRAU \\ Universitat de València \\ (con la ayuda de Claudia SimÓn y LAURA ViCIANO \\ Biblioteca Valenciana de San Miguel de los Reyes)
}

\author{
I. LA LENGUA ESPAÑOLA Y SU GRAMÁTICA \\ II. HISTORIA DE LA LENGUA \\ III. FONÉTICA Y FONOLOGÍA HISTÓRICAS \\ IV. MORFOSINTAXIS HISTÓRICA \\ V. LÉXICO \\ VI. ETIMOLOGÍA \\ VII. DIALECTOLOGÍA \\ VIII. ESTUDIOS LITERARIOS \\ IX. HISTORIA LITERARIA: EDAD MEDIA \\ $X$. HISTORIA LITERARIA: SIGLO XV \\ XI. HISTORIA LITERARIA: SIGLO XVI \\ XII. HISTORIA LITERARIA: SIGLO XVII \\ XIII. HISTORIA LITERARIA: SIGLO XVIII \\ XIV. HISTORIA LITERARIA: SIGLO XIX \\ XV. HISTORIA LITERARIA: SIGLO XX \\ XVI. EDICIÓN DE TEXTOS DE LA LITERATURA ESPAÑOLA \\ XVII. EDICIÓN DE OBRAS AJENAS \\ XVIII. RESEÑAS \\ XIX. PRÓLOGOS \\ XX. DISCURSOS \\ XXI. CONTESTACIONES A DISCURSOS \\ XXII. SOBRE AUTORES CONTEMPORÁNEOS \\ XXIII. NECROLÓGICAS \\ XXIV. OTROS \\ XXV. INÉDITOS
}




\section{LA LENGUA ESPAÑOLA Y SU GRAMÁTICA}

1. "Sugestiones relacionadas con la futura edición de la Gramática de la Real Academia Española. Conveniencia de tener en cuenta otras gramáticas de mérito notable", Memoria del Segundo Congreso de Academias de la Lengua Española, Madrid, págs. 83-88. (Publicado con el título de "Hacia una nueva Gramática de la RAE", Cuadernos Hispanoamericanos, 78-79, 1956, págs. 323337. También en El español moderno y contemporáneo. Estudios lingüísticos, Barcelona, Crítica, 1996, págs. 157-162).

2. "El género gramatical de los pueblos y ríos españoles", $A B C, 8$ de agosto de 1962, pág. 25.

3. "Tendencias y problemas actuales de la lengua española", en Rafael Lapesa (coord.), Comunicación y Lenguaje, Instituto de Ciencias del Hombre, Madrid, Karpos, 1976, págs. 203-229. (Reproducido en El español moderno y contemporáneo. Estudios lingüísticos, Barcelona, Crítica, 1996, págs. 422459).

4. "El Esbozo de una nueva gramática de la Real Academia Española", Lingüística y educación. Actas del IV Congreso Internacional de la ALFAL, Lima, Universidad Nacional Mayor de San Marcos, 1978, págs. 76-85. (Reproducido en El español moderno y contemporáneo. Estudios lingüísticos, Barcelona, Crítica, 1996, págs. 163-173).

5. "Unidad y variedad de la lengua española", Cuenta y razón del pensamiento actual, 8, otoño 1982, págs. 21-33. (Versión muy ampliada en El español moderno y contemporáneo. Estudios lingüísticos, Barcelona, Crítica, 1996, págs. 317-340).

6. "La lengua", en Luis Racionero, Un solo mundo. 1492-1992, Madrid, Sociedad Estatal Quinto Centenario; Barcelona, Lunwerg, 1991, págs. 107-114.

7. “La lengua española en el Quinto Centenario", Estudios Internacionales 1992, Madrid, Sociedad de Estudios Internacionales, 1992, págs. 91-99.

8. "La lengua española en el mundo", Premios Cervantes. Una literatura en dos continentes. Exposición itinerante, Madrid, Ministerio de Cultura, Dirección General de Archivos y Bibliotecas, Centro de las letras españolas, 1994, págs. 15-25.

9. "La lengua", en Ramón Menéndez Pidal, Historia de España, vol. XXXIX, 2, La edad de plata de la cultura española (1898-1936). Madrid, Espasa-Calpe, 1994, págs. 5-40.

10. "Nuestra lengua en la España de 1898 a 1936", El español moderno y contemporáneo. Estudios lingüísticos, Barcelona, Crítica, 1996, págs. 343-413.

11. El español moderno y contemporáneo. Estudios lingüísticos, Barcelona, Crítica, 1996. (Contiene los trabajos 1, 3, 4, 5, 10, 55, 72, 79, 83, 84, 90, 91, 92, 93, $107,111,214,221,305,321,325,327,428,432$ у 436).

12. "España, creadora de una lengua universal”, España: reflexiones sobre el ser de España, Madrid, Real Academia de la Historia, 1997, págs. 499-534.

Véase también 264, 284, 286, 291, 297, 305, 306, 317, 327, 330 y 431. 


\section{HISTORIA DE LA LENGUA}

13. "Algunos aspectos lingüísticos del Cantar de Mio Cid”, Mio Cid, V, 1941, págs. 57-58.

14. Historia de la lengua española, Madrid, Escelicer, 1942, 360 págs.

15. Formación e historia de la lengua española. Adaptación para cuarto año de Bachillerato, Madrid, Librería de Enrique Prieto, 1943, 224 págs.

16. Asturiano y provenzal en el Fuero de Avilés, Salamanca, Universidad de Salamanca (Acta Salmanticensia: Filosofía y Letras, II, 4), 1948, 110 págs. (Reimpreso en Estudios de historia lingüística española, Madrid, Paraninfo, 1985, págs. 53-122).

17. Historia de la lengua española, segunda edición corregida y aumentada, Madrid, Escelicer, 1951, 386 págs.

18. Historia de la lengua española, tercera edición corregida y aumentada, Madrid, Escelicer, s.a. [1955], 390 págs.

19. "Desarrollo de las lenguas ibero-románicas durante los siglos V al XIII", Cahiers d'Histoire Mondiale, V, 3, 1959, págs. 573-605.

20. Historia de la lengua española, cuarta edición corregida y aumentada, Madrid, Escelicer, 1959.

21. Historia de la lengua española, quinta edición, Madrid, Escelicer, 1962, 421 págs.

22. "El lenguaje del Fuero de Madrid y glosario", El Fuero de Madrid, Madrid, Ayuntamiento de Madrid, Archivo de la Villa, 1963, págs. 151-163. (Reimpreso con el título de "El Fuero de Madrid" en Estudios de historia lingüística española, Madrid, Paraninfo, 1985, págs. 157-163).

23. "La lengua en los últimos cuarenta años", Revista de Occidente, 8-9, 1963, págs. 193-208.

24. Historia de la lengua española, sexta edición, Madrid, Escelicer, 1965, 424 págs.

25. "Los 'francos' en la Asturias medieval y su influencia lingüística”, Symposium sobre cultura asturiana de la Alta Edad Media. Septiembre de 1961. Oviedo, Excmo. Ayuntamiento de Oviedo. XII centenario de la fundación de la ciudad de Oviedo, 1967, págs. 341-353. (Reimpreso en Estudios de historia lingüística española, Madrid, Paraninfo, 1985, págs. 43-52).

26. Historia de la lengua española, séptima edición, Madrid, Escelicer, 1968, 424 págs.

27. "Los provenzalismos del Fuero de Valfermoso de las Monjas (1189)", Hispanic Studies in honor of Edmund de Chasca, Philological Quarterly, LI, 1, 1972, págs. 54-59. (Reimpreso en Estudios de historia lingüística española, Madrid, Paraninfo, 1985, págs. 123-127).

28. "Rasgos franceses y occitanos en el lenguaje del Fuero de Villavaruz de Rioseco (1181)", en Mélanges de Linguistique Française et de Philologie et Littérature médiévales offerts à monsieur Paul Imbs, Travaux de Linguistique et Littérature, XI, 1, Strasbourg, 1973, págs. 529-532. (Reimpreso en Estudios de historia lingüística española, Madrid, Paraninfo, 1985, págs. 128-131). 
29. "Una lengua más que milenaria", El País, 15, 16 y 17 de noviembre de 1977. (Reunidos los tres artículos en Revista de Información de la Comisión Nacional Española de Cooperación con la UNESCO, oct-dic 1977, 12.

30. "Origen y evolución de la lengua española", Estudios segovianos, XXIX, 85, 1978, págs. 231-250.

31. "De cómo el castellano pasó a ser el español”, Boletín Corporativo de la Academia Burgense, 190, 1978, págs. 35-48. (Publicado también en Boletín de la Asociación Europea de Profesores de Español, 19, octubre 1978, págs. 27-37).

32. Historia de la lengua española, octava edición refundida y muy aumentada, Madrid, Gredos, 1980, 682 págs.

33. Historia de la lengua española, novena edición, corregida y aumentada, Madrid, Gredos, 1981, 690 págs.

34. "Contienda de normas lingüísticas en el castellano alfonsî", en Wido Hempel y Dietrich Briesemeister (eds.), Actas del coloquio hispano-alemán Ramón Menéndez Pidal. (Madrid, 31 de marzo a 2 de abril de 1978), Tübingen, Max Niemeyer, 1982, págs. 172-190. (Reimpreso en Estudios de historia lingüística española, Madrid, Paraninfo, 1985, págs. 209-225).

35. Estudios de historia lingüística española, Madrid, Paraninfo, 1985, 306 págs. (Contiene los trabajos 16, 22, 25, 27, 28, 34, 40, 42, 43, 103, 106, 134, 135, 136, 137 y 141).

36. "El Fuero de Valfermoso de las Monjas (1189)", Homenaje a Álvaro Galmés de Fuentes, I, Madrid, Gredos, 1985, págs. 43-98. [El “Texto del Fuero", en colaboración con Ramón Menéndez Pidal y Gonzalo Menéndez Pidal].

37. "El español del Siglo de Oro. Cambios lingüísticos generales", Estudios lingüísticos, literarios y estilísticos, Valencia, Universitat de València, 1987, págs. 5-32. (Reproduce párrafos de las páginas 367-417 de la Historia de la lengua española, $9^{\mathrm{a}}$ ed., Madrid, Gredos, 1981).

38. "Historia de una Historia de la lengua española", Actas del I Congreso Internacional de Historia de la Lengua Española, II, Madrid, Arco-Libros, 1988, págs. 1771-1785.

39. "España y los españoles. España y sus lenguas en la Edad Media”, en R. de las Heras, Valerio Báez San José y Pilar Amador Carretero (eds.), Sobre la realidad de España, Madrid, Universidad Carlos III de Madrid, 1994, págs. 189-208.

Véase también 128, 130, 134, 137, 145, 146, 177, 186, 194, 203, 207, 211, 213, $214,219,254,260,280,282,293,300,303,314,325,415,433,442$ у 444.

\section{FONÉTICA Y FONOLOGÍA HISTÓRICAS}

40. "La apócope de la vocal en castellano antiguo. Intento de explicación histórica", Estudios dedicados a Menéndez Pidal, II, Madrid, CSIC, 1951, págs. 185226. (Reimpreso en Estudios de historia lingüística española, Madrid, Paraninfo, 1985, págs. 167-197). 
41. "Sobre el ceceo y seseo en Hispanoamérica", Homenaje a Pedro Henríquez Ureña, Revista Iberoamericana, XXI, 1956, págs. 409-416.

42. "Sobre el ceceo y seseo andaluces", Estructuralismo e Historia. Miscelánea Homenaje a André Martinet, I, La Laguna, Universidad de La Laguna, 1957, págs. 67-94. (Reimpreso en Estudios de historia lingüística española, Madrid, Paraninfo, 1984, págs. 249-266).

43. "De nuevo sobre la apócope vocálica en castellano medieval", NRFH, XXIX, Homenaje a Raimundo Lida, 1975, págs. 13-23. (Reimpreso en Estudios de historia lingüística española, Madrid, Paraninfo, 1985, págs. 198-208).

44. "Más sustituciones de /f/ inicial por otras labiales, y viceversa, en español primitivo", Serta gratulatoria in honorem Juan Régulo, I, La Laguna, Universidad de La Laguna, 1985, págs. 401-404.

45. "Sobre equivalencias italianas de la ch española", Dialogo. Studi in onore di Lore Terracini, Roma, Bulzoni, 1990, págs. 269-276.

\section{MORFOSINTAXIS HISTÓRICA}

46. "Sobre las construcciones 'con sola su figura', 'Castilla la gentil' y similares", Ibérida, 6, 1961, Homenaje a Marcel Bataillon, págs. 83-95. (Reimpreso en Estudios de morfosintaxis histórica del español, Madrid, Gredos, 2000, págs. 123-136).

47. "Del demostrativo al artículo", NRFH, XV, 1961, Homenaje a Alfonso Reyes, págs. 23-44. (Reimpreso en Estudios de morfosintaxis histórica del español, Madrid, Gredos, 2000, págs. 360-387).

48. 'Sobre las construcciones 'el diablo del toro', 'el bueno de Minaya', ‘jay de mí!’, ‘pobre de Juan!', 'por malos de pecados’”, Filología, VIII, 1962, págs. 169-184. (Reimpreso en Estudios de morfosintaxis histórica del español, Madrid, Gredos, 2000, págs. 137-153).

49. "Los casos latinos: restos sintácticos y sustitutos en español", BRAE, XLIV, 171, 1964, págs. 57-106. (Reimpreso en Estudios de morfosintaxis histórica del español, Madrid, Gredos, 2000, págs. 73-122).

50. "El artículo como antecedente de relativo en español", Estudios de filología e historia literaria lusohispanas e iberoamericanas publicados para celebrar el tercer lustro del Instituto de Estudios Hispánicos, portugueses e iberoamericanos de la Universidad estatal de Utrecht, La Haya, Van Goor Zoonen, 1966, págs. 187-298. (Publicado con enmiendas y adiciones, bajo el título de “"El', 'la', 'lo' como antecedente de relativo en español”, en Francisco Marcos Marín, Aproximación a la gramática española, $2^{\mathrm{a}}$ ed. Madrid, Cincel, 1974, págs. IX-XVII; reimpreso en Estudios de morfosintaxis histórica del español, Madrid, Gredos, 2000, págs. 388-401).

51. "Evolución sintáctica y forma lingüística interior en español", Actas del XI Congreso Internacional de Lingüística y Filología Románicas, Madrid, CSIC, 1968, págs. 131-150. (Reimpreso en Estudios de morfosintaxis histórica del español, Madrid, Gredos, 2000, págs. 32-53). 
52. "Sobre los orígenes y evolución del leísmo, laísmo y loísmo", Festschrift Walther von Wartburg zum 80. Geburstag, Tübingen, Max Niemeyer, 1968, págs. 523-551. (Reimpreso en Estudios de morfosintaxis histórica del español, Madrid, Gredos, 2000, págs. 279-310).

53. "La ruptura de la consecutio temporum en Bernal Díaz del Castillo", Anuario de Letras, VII, 1968-1969 [1970], págs. 73-83. (Reimpreso en Estudios de morfosintaxis histórica del español, Madrid, Gredos, 2000, págs. 671-681).

54. "El artículo con calificativos o participios no adjuntos al sustantivo en español", Phonétique et Linguistique Romanes. Mélanges offerts à M. Georges Straka, II, Lyon-Strasbourg, 1970, págs. 78-86. (Reimpreso en Estudios de morfosintaxis histórica del español, Madrid, Gredos, 2000, págs. 402-412).

55. "Las formas verbales de segunda persona y los orígenes del voseo", Actas del III Congreso Internacional de Hispanistas, México, El Colegio de México, 1970, págs. 519-531. (Reimpreso en El español moderno y contemporáneo. Estudios lingüísticos, Barcelona, Crítica, 1996, págs. 253-267; también en Estudios de morfosintaxis histórica del español, Madrid, Gredos, 2000, págs. 682-697).

56. "Personas gramaticales y tratamiento en español", Revista de la Universidad de Madrid, XIX, 1970, Homenaje a Menéndez Pidal, IV, págs. 167-193. (Reimpreso en Estudios de morfosintaxis histórica del español, Madrid, Gredos, 2000, págs. 311-345).

57. "Sobre problemas y métodos de una sintaxis histórica", Homenaje a Xavier Zubiri, II, Madrid, Sociedad de Estudios y Publicaciones, 1970, págs. 199213. (Reimpreso en Buscad sus pares, pocos, publicado por la "CátedraSeminario Menéndez Pidal", de la Universidad Complutense de Madrid, Madrid, Gredos, 1978, págs. 25-48; también en Estudios lingüísticos, literarios y estilísticos, Valencia, Universitat de València, 1987, págs. 35-45; y en Estudios de morfosintaxis histórica del español, Madrid, Gredos, 2000, págs. 54-69).

58. "Sobre el artículo ante posesivo en castellano antiguo", Sprache und Geschichte. Festschrift für Harri Meier, München, Wilhelm Fink, 1971, págs. 277-296. (Reimpreso en Estudios de morfosintaxis histórica del español, Madrid, Gredos, 2000, págs. 413-435).

59. "Un, una as the Indefinite Article in Spanish", Papers in Linguistics in Honor of Henry and Renée Kahane, University of Illinois Press, 1973, págs. 492503. (Publicado en español, con el título de "Un, una como artículo indefinido en español", en Boletín de la Academia Puertorriqueña de la Lengua, II, 1974; revisado y publicado junto a "El sustantivo sin actualizador en español" con el título de "Dos estudios sobre la actualización del sustantivo en español”, en Boletín de la Comisión Permanente de la Real Academia Española, 21, 1975, Madrid, 1976, págs. 3-31; reproducido en Estudios lingüísticos, literarios y estilísticos, Valencia, Universitat de València, 1987, págs. 49-56; también en Estudios de morfosintaxis histórica del español, Madrid, Gredos, 2000, págs. 477-487).

60. "El sustantivo sin actualizador en español”, Homenaje a Ángel Rosenblat en sus 70 años, Caracas, Instituto Pedagógico, 1974, págs. 289-304. (Publicado 
publicado junto a "Un, una como artículo indefinido en español", con el título de "Dos estudios sobre la actualización del sustantivo en español", en Boletín de la Comisión Permanente de la Real Academia Española, 21, 1975, Madrid, 1976, págs. 3-31; reimpreso en Estudios lingüísticos, literarios y estilísticos, Valencia, Universitat de València, 1987, págs. 57-68; también en Estudios de morfosintaxis histórica del español, Madrid, Gredos, 2000, págs. 436-454).

61. "La colocación del adjetivo calificativo atributivo en español", Homenaje a la memoria de don Antonio Rodríguez-Moñino1910-1970, Madrid, Castalia, 1975, págs. 329-345. (Reimpreso en Estudios de morfosintaxis histórica del español, Madrid, Gredos, 2000, págs. 210-234).

62. "Sintaxis histórica del adjetivo calificativo no atributivo", Homenaje al Instituto de Filología y Literatura "Dr. Amado Alonso" en su cincuentenario (19231973), Buenos Aires, 1975, págs. 171-199. (Reimpreso en Estudios de morfosintaxis histórica del español, Madrid, Gredos, 2000, págs. 235-271).

63. "Sobre dos tipos de subordinación causal”, Estudios ofrecidos a Emilio Alarcos Llorach, III, Oviedo, Universidad de Oviedo, 1978, págs. 173-205. (Reimpreso en Estudios de morfosintaxis histórica del español, Madrid, Gredos, 2000, págs. 896-927).

64. "Nominativo o caso oblicuo latinos como origen de demostrativos y artículo castellanos", Festschrift Kurt Baldinger zum 60 Geburstag, Tübingen, Max Niemeyer, 1979, págs. 196-207. (Reimpreso en Estudios de morfosintaxis histórica del español, Madrid, Gredos, 2000, págs. 346-359).

65. "Sobre las perífrasis causativas con participio", Homenaje a Samuel Gili Gaya, Barcelona, Biblograf, 1979, págs. 113-117. (Reimpreso en Estudios de morfosintaxis histórica del español, Madrid, Gredos, 2000, págs. 698-704).

66. "El infinitivo con actualizador en español: condicionamiento sintáctico de su forzosidad o su rechazo", Serta Philologica F. Lázaro Carreter, Madrid, Cátedra, 1983, págs. 279-299. (Reimpreso en Estudios de morfosintaxis histórica del español, Madrid, Gredos, 2000, págs. 557-591).

67. "El uso de actualizadores con el infinitivo y la subordinación sustantiva en español: diacronía y sentido", Homenaje a Ana María Barrenechea, Madrid, Castalia, 1984, págs. 65-89. (Reimpreso en Estudios de morfosintaxis histórica del español, Madrid, Gredos, 2000, págs. 515-556).

68. "El neutro en calificativos y determinativos castellanos", Miscel-lània Sanchis Guarner. II. Quaderns de Filologia, Universitat de València, 1984, págs. 173-187. (Reimpreso en Estudios de morfosintaxis histórica del español, Madrid, Gredos, 2000, págs. 167-209).

69. "Uso potestativo de actualizador con infinitivo", Philologica Hispanensia in honorem Manuel Alvar, II, Madrid, Gredos, 1985, págs. 317-373. (Reimpreso en Estudios de morfosintaxis histórica del español, Madrid, Gredos, 2000, págs. 592-668).

70. "Sobre el uso de modos y tiempos en subordinaciones de acción futura o contingente: futuro de indicativo por presente o futuro de subjuntivo", Symbolae Ludovico Mitxelena Septuagenario Oblatae, Victoriaco Vasconum [VitoriaGasteiz], Universidad del País Vasco, 1985, págs. 679-692. (Reimpreso en 
Estudios de morfosintaxis histórica del español, Madrid, Gredos, 2000, págs. 705-729).

71. "Uso o ausencia del artículo el, la, los, las con numerales", Scripta Philologica in honorem Juan M. Lope Blanch, I, México, UNAM, 1992, págs. 359-381. (Reimpreso en Estudios de morfosintaxis histórica del español, Madrid, Gredos, 2000, págs. 488-514).

72. "La interpolación del sujeto en las oraciones interrogativas", Actas del II Congreso Internacional de Historia de la Lengua Española, I, Madrid, Pabellón de España, 1992, págs, 545-553. (Reimpreso, con el título de "La interpolación caribeña del sujeto en las oraciones interrogativas", en El español moderno y contemporáneo. Estudios lingüísticos, Barcelona, Crítica, 1996, págs. 305-316. También en Estudios de morfosintaxis histórica del español, Madrid, Gredos, 2000, págs. 154-166).

73. "Sobre el adjetivo complementario circunstancial", Estudis de lingüística $i$ filologia oferts a Antoni Badia i Margarit, I, Barcelona, Universitat de Barcelona-Publicacions de l'Abadia de Montserrat, 1995-1996, págs. 531-536. (Reimpreso en Estudios de morfosintaxis histórica del español, Madrid, Gredos, 2000, págs. 272-278).

74. "Morfosintaxis histórica del verbo español”, preparado y dispuesto para la imprenta por Rafael Cano Aguilar, en Estudios de morfosintaxis histórica del español, Madrid, Gredos, 2000, págs. 730-885.

75. Estudios de morfosintaxis histórica del español, edición de Rafael Cano Aguilar y $\mathrm{M}^{\mathrm{a}}$ Teresa Echenique Elizondo, Madrid, Gredos, 2000, 945 págs. (Contiene los trabajos 46, 47, 48, 49, 50, 51, 52, 53, 54, 55, 56, 57, 58, 59, 60, 61, 62, $63,64,65,66,67,68,69,70,71,72,73,74,203,260,264$, у 319).

Véase también 2, 203, 228, 260, 264, 308, 309 y 319.

\section{LÉXICO}

76. "Notas para el léxico del siglo XIII”, RFE, XVIII, 1931, págs. 113-119. (Reimpreso en Léxico e historia. I. Palabras, Madrid, Istmo, 1992, págs. 19-26).

77. Glosario con nota preliminar a G. Sánchez, Fuero de Madrid y los derechos locales castellanos, texto y transcripción por Agustín Millares Carlo, Madrid, Artes Gráficas Municipales, 1932.

78. "Colaboración de las Academias de la Lengua al Diccionario Histórico", Memoria del Segundo Congreso de Academias de la Lengua Española, Madrid, 1956, págs. 389-392. (Publicado con el título de "El Diccionario Histórico", Cuadernos Hispanoamericanos, 78-79, 1956, págs. 339-341; también en Léxico e Historia. II. Diccionarios, Madrid, Istmo, 1992, págs. 19-23).

79. "Le dictionnaire historique de la langue espagnole", Lexicologie et Lexicographie françaises et romanes [Strasbourg, 12-16 nov., 1957], Paris, CNRS, 1960, págs. 21-27. (Publicado en español con el título de "El Diccionario Histórico de la Lengua Española”, Léxico e Historia. II. Diccionarios, Madrid, Istmo, 1992, págs. 31-40. También en El español moderno y contemporáneo. Estudios lingüísticos, Barcelona, Crítica, 1996, págs. 180-188). 
80. Real Academia Española, Seminario de Lexicografía, Diccionario Histórico de la Lengua Española, Madrid, t. I (a-ala), 1960-72; t. II (alaba-antígrafo), 1992; t. III, fascículo 1.․ (antigramatical-aonio), 1993; t. III, fascículo $2 .{ }^{\circ}$ (aonio-apasanca), 1996; t. IV, fascículo 1. ${ }^{\circ}$ (b-bajoca), 1996. Rafael Lapesa fue Colaborador (1947-1950), Subdirector (1950-1969), Director (1969-1981) y Director honorario (1981-1996) del Seminario de Lexicografía de la Real Academia Española.

81. "Informe relativo al Diccionario Histórico de la Lengua Española”, Tercer Congreso de Academias de la Lengua Española, Bogotá, 1961, págs. 103107. (Publicado también en Léxico e Historia. II. Diccionarios, Madrid, Istmo, 1992, págs. 25-30).

82. "Los diccionarios de la Academia", BRAE, XLIV, 1964, págs. 425-430. (Publicado también en Actas y labores. IV Congreso de Academias de la Lengua Española celebrado en Buenos Aires del 30 de Noviembre al 10 de Diciembre de 1964. Buenos Aires, Ediciones de la Academia Argentina de Letras, 1966, págs. 229-231; también en Léxico e Historia. II. Diccionarios, Madrid, Istmo, 1992, págs. 13-18).

83. "Kahlahtahyood. Madariaga ha puesto el dedo en la llaga", Revista de Occidente, 36, 1966, págs. 373-380. (Reimpreso en Evolución y permanencia del idioma, Cuenca (Ecuador), Universidad de Cuenca, 1966. También en El español moderno y contemporáneo. Estudios lingüísticos, Barcelona, Crítica, 1996, págs. 414-421).

84. "Ideas y palabras: del vocabulario de la Ilustración al de los primeros liberales", Asclepio. Archivo Iberoamericano de Historia de la Medicina, XVIIIXIX, Homenaje a Pedro Laín Entralgo, 1966-1967, págs. 189-218. (Publicado también en Boletín de la Academia Peruana de la Lengua, I. Lima, 1967, págs. 67-104; también en El español moderno y contemporáneo. Estudios ligüísticos, Barcelona, Crítica, 1996, págs. 11-42).

85. "Notas lexicológicas", Sonderdruck aus der Festschrift Litterae Hispaniae et Lusitaniae. Festschrift zum fünfzigjahrigen bestegen des Ibero-Amerikanischen forschunginstitut der Universität Hamburg, herausgegeben von Hans Flasche, Munchen, Universität Hamburg, Max Hueber, 1968, págs. 189-193. (Reimpreso en Léxico e historia. I. Palabras, Madrid, Istmo, 1992, págs. 45-51).

86. "La toponimia como herencia histórica y lingüística", Las Ciencias, XXXIV, 1969, págs. 239-251. (Reimpreso en Léxico e historia. I. Palabras, Madrid, Istmo, 1992, págs. 169-189).

87. "Sobre la transliteración de nombres propios extranjeros", BRAE, LIII, 1973, págs. 279-287.

88. "Español antiguo linencia, linenciar, linencioso", en Hans-Dieter Bork et al. (eds.), Sonderdruck Romanica Europaea et Americana, Festschrift für Harri Meier, 8 Januar 1980, Bonn, Bouvier, 1980, págs. 326-330. (Reimpreso en Léxico e historia. I. Palabras, Madrid, Istmo, 1992, págs. 57-63).

89. “Ínsula, palabra y aventura”, Ínsula, 400-401, 1980, págs. 1-24. (Reimpreso en Léxico e historia. I. Palabras, Madrid, Istmo, 1992, págs. 53-56).

90. “Alma y ánima en el Diccionario Histórico de la Lengua Española”, BRAE, LX, 1980, págs. 183-195. (Reimpreso en Léxico e historia. II. Diccionarios, 
Madrid, Istmo, 1992, págs. 65-78. También en El español moderno y contemporáneo. Estudios lingüísticos, Barcelona, Crítica, 1996, págs. 189-200).

91. "Alma y ánima en el Diccionario Histórico de la Lengua Española: su fraseología”, Logos Semantikós. Studia linguistica in honorem Eugenio Coseriu, III, Madrid-Berlín-Nueva York, Gredos-de Gruyter, págs. 223-228. (Reimpreso en Léxico e historia. II. Diccionarios, Madrid, Istmo, 1992, págs. 7986. También en El español moderno y contemporáneo. Estudios lingüísticos, Barcelona, Crítica, 1996, págs. 200-206).

92. "Necesidad de una política hispánica sobre neologismos técnicos y científicos", Telos. Cuadernos de Comunicación, Tecnología y Sociedad, 5, enero-marzo 1986, págs. 84-89. [Ponencia leída en la sesión inaugural del Consejo de Academias de la Lengua celebrado en Madrid del 7 al 10 de octubre de 1985]. (Publicado también en Primera reunión de Academias de la Lengua Española sobre el lenguaje y los medios de comunicación (octubre 1985), Madrid, Real Academia Española, 1987, págs. 19-25. También en El español moderno y contemporáneo. Estudios lingüísticos, Barcelona, Crítica, 1996, págs. 211-220).

93. "Algunas consideraciones sobre el léxico político en los años de Larra y Espronceda", Homenaje a José Antonio Maravall, Madrid, Centro de Investigaciones Sociológicas, 1985-1986, págs. 393-413. (Reimpreso en El español moderno y contemporáneo. Estudios lingüísticos, Barcelona, Crítica, 1996, págs. 111-136).

94. "Palabras y cosas. El vocabulario de la vida social y la indumentaria durante el romanticismo", Estudios. Homenaje al profesor Alfonso Sancho Sáez, I, Granada, Universidad de Granada, 1989, págs. 397-412. (Reimpreso en El espanol moderno y contemporáneo. Estudios lingüísticos, Barcelona, Crítica, 1996, págs. 137-154).

95. Léxico e historia. I. Palabras, volumen preparado por Juan R. Lodares en colaboración con el autor, Madrid, Istmo, 1992, 232 págs. (Contiene los trabajos $76,85,86,88,89,98,101,102,103,104,105,135,175,176,199,255,263$ y 322 ).

96. Léxico e historia. II. Diccionarios, volumen preparado por Juan R. Lodares en colaboración con el autor, Madrid, Istmo, 1992, 120 págs. (Contiene los trabajos 78, 79, 81, 82, 90, 91, 96, 270, 283, 289, 290, 332, 335, 336 у 337).

97. "Sobre el concepto exclusivista del americanismo lingüístico: sus consecuencias en la lexicografía actual", Homenaje a Humberto López Morales, Madrid, Arco/Libros, 1992, págs. 35-39.

98. "Chanzón, chanzoneta, chancha, chanza, chanzaina, chanfaina y sus derivados", Homenaje a Félix Monge: estudios de lingüística hispánica, Madrid, Gredos, 1995, págs. 233-247. (Reimpreso en Léxico e historia. I. Palabras, Madrid, Istmo, 1992, págs. 87-111).

99. Glosario del primitivo léxico ibero-románico. Proyecto de informatización. Homenaje a Rafael Lapesa en sus noventa años, 8-II-1998, Madrid, Fundación Ramón Menéndez Pidal y Seminario Menéndez Pidal-Universidad Complutense de Madrid, 1998. [Muestra de la ampliación del Glosario del español primitivo emprendida por Rafael Lapesa —aún inédita - y cuya publicación se anuncia en este libro]. 
100. Léxico hispánico primitivo (siglos VIII al XII). Versión primera del Glosario del primitivo léxico iberorrománico, proyectado y dirigido inicialmente por Ramón Menéndez Pidal; redactado por Rafael Lapesa; con la colaboración de Constantino García, Madrid, Fundación Ramón Menéndez Pidal-Real Academia Española, 2003.

Véase también 135, 175, 176, 178, 199, 254, 255, 263, 270, 277, 283, 289, 290, $299,304,306,317,322,332,335,336,337,340$ у 421.

\section{ETIMOLOGÍA}

101. "Derivados españoles de sulcus", RFE, XVI, 1930, págs. 169-173. (Reimpreso en Léxico e historia. I. Palabras, Madrid, Istmo, 1992, págs. 13-17).

102. "Notas etimológicas", RFE, XXIII, 1936, págs. 402-409. (Reimpreso en Léxico e historia. I. Palabras, Madrid, Istmo, 1992, págs. 31-40).

103. "No es desdoro que español sea un provenzalismo", Ya, 14 de enero de 1971. (Publicado con adiciones y notas como prólogo al libro de Américo Castro "Sobre el nombre y el quién de los españoles", Madrid, Taurus, 1973. Reimpreso con más adiciones y un apéndice, con el título de "Sobre el origen de la palabra español" en Estudios de historia lingüística española, Madrid, Paraninfo, 1985, págs. 132-137. Esta última versión se reproduce en Léxico e historia. I. Palabras, Madrid, Istmo, 1992, págs. 79-86).

104. "Notas etimológicas y semánticas", Hommage à Bernard Pottier, Paris, Klincksieck, 1988, págs. 469-476. (Reimpreso en Léxico e historia. I. Palabras, Madrid, Istmo, 1992, págs. 65-77).

105. "Sobre el origen de Sancho”, en Dieter Kremer (ed.), Homenagem a Joseph M. Piel por ocasião do seu $85^{\circ}$ aniversário, Tübingen, Max Niemeyer, 1988, págs. 97-83. (Reimpreso en Léxico e historia. I. Palabras, Madrid, Istmo, 1992, págs. 199-205).

Véase también 285.

\section{DiALECTOLOGÍA}

106. "El andaluz y el español de América", Presente y futuro de la Lengua Española, II, Madrid, Ediciones Cultura Hispánica, págs. 173-182. (Reimpreso en Estudios de historia lingüística española, Madrid, Paraninfo, 1985, págs. 267-282).

107. "América y la unidad de la lengua española", Revista de Occidente, IV, 38, 1966, págs. 300-310. (Reproducido en El español moderno y contemporáneo. Estudios lingüísticos, Barcelona, Crítica, 1996, págs. 241-252).

108. "El dialecto asturiano-occidental en los documentos notariales de la baja Edad Media”, Revista de Dialectología y Tradiciones Populares, XXXII, Homena- 
je a Vicente García de Diego, 1976, págs. 225-245. (Publicado con una adición final, con el título de "Tendencias en la normalización del asturiano medieval", en Estudios y trabayos del Seminariu de Llingua Asturiana, II, Universidá d'Uvieu, 1979, págs. 25-46).

109. "Orígenes y expansión del español atlántico", Rábida, diciembre, 1985 , págs. 43-54. (Reproducido en Demófilo: revista de cultura tradicional, 22, 1997, págs. 13-28).

110. "El español de América", en Luis Racionero, Un solo mundo. 1492-1992, Madrid, Sociedad Estatal Quinto Centenario; Barcelona, Lunwerg, 1991, págs. 383-385.

111. "El estudio del español americano en los últimos decenios: aportaciones y cuestiones pendientes", El español de América. Actas del III Congreso Internacional de El español de América, (Valladolid, 3-9 de julio de 1989), I, Salamanca, Junta de Castilla y León, 1991, págs. 7-28. (Reproducido en El español moderno y contemporáneo. Estudios lingüísticos, Barcelona, Crítica, 1996, págs. 268-304).

112. "El español llevado a América", Historia y presente del español de América, Valladolid, Junta de Castilla y León-Pabecal, 1992, págs. 11-24. (Publicado con el título de "La lengua española en América durante el primer siglo de la colonización", Actas del Congreso de Historia del Descubrimiento, IV, Madrid, Real Academia de la Historia, 1992, págs. 97-111).

113. "Nuestra lengua en España y en América", RFE, LXXII, 3-4, 1992, págs. 269282.

114. El dialecto asturiano occidental en la Edad Media, Sevilla, Universidad de Sevilla, 1998.

Véase también 16, 19, 25, 41, 42, 72, 97, 129, 137, 253, 279, 283, 287, 298, $313,328,421$ y 443.

\section{ESTUDIOS LITERARIOS}

115. Introducción a los estudios literarios, para cuarto año de Bachillerato, Barcelona, Editorial Rauter, 1947, 180 págs.

116. Introducción a los estudios literarios, segunda edición, Salamanca-Madrid-Barcelona, Anaya, 1964.

117. Introducción a los estudios literarios, reimpresión, Salamanca-Madrid-Barcelona, Anaya, 1965.

118. Introducción a los estudios literarios, reimpresión, Salamanca-Madrid-Barcelona, Anaya, 1966.

119. De la Edad Media a nuestros días, Madrid, Gredos, 1967, 310 págs. (Contiene los trabajos 127, 130, 131, 132, 142, 149, 153, 164, 170, 171, 183, 198, 199, 200, 201, 202, 206, 212 у 216).

120. Introducción a los estudios literarios, reimpresión, Salamanca-Madrid-Barcelona-Caracas, Anaya, 1968.

121. De la Edad Media a nuestros días, reimpresión, Madrid, Gredos, 1971. 
122. Poetas y prosistas de ayer y de hoy. Veinte estudios de historia y crítica literarias, Madrid, Gredos, 1977, 424 págs. (Contiene los trabajos 133, 155, 156, $176,178,180,203,204,217,223,224,226,265,271,274,275,288,323$, 348 y 350 ).

123. De la Edad Media a nuestros días. $2^{\mathrm{a}}$ reimpresión, Madrid, Gredos, 1982.

124. De Ayala a Ayala. Estudios literarios y estilísticos, Madrid, Istmo, 1988, 360 págs. (Contiene los trabajos 126, 138, 158, 184, 185, 186, 189, 194, 195, 205, 207, 218, 228, 229, 231, 232, 338 y 339).

125. De Berceo a Jorge Guillén. Estudios literarios, Madrid, Gredos, 1997. (Contiene los trabajos 139, 160,161, 162, 163, 190, 192, 193, 210, 215, 235, 236, $278,363$ y 364$)$.

Véase también 262, 301, 416 y 433.

\section{Historia LITERARIA: EDAD MEDIA}

126. "El Canciller Ayala y otros poemas del mester de clerecía en el siglo XIV", en Historia General de las Literaturas Hispánicas, I, Barcelona, Barna, 1949, págs. 491-517. (Reproducido, con el título de "El Canciller Ayala", en De Ayala a Ayala. Estudios literarios y estilísticos, Madrid, Istmo, 1988, págs. 9-37).

127. "Sobre el Auto de los Reyes Magos: Sus rimas anómalas y el posible origen de su autor", Homenaje a Fritz Krüger, II, Mendoza, Universidad Nacional de Cuyo, 1954, págs. 591-599. (Reimpreso en De la Edad Media a nuestros días, Madrid, Gredos, 1967, págs. 37-47).

128. "Sobre el texto y lenguaje de algunas 'jarchyas' mozárabes”, BRAE, XL, 161, 1960, págs. 52-65.

129. "Ofrenda de tres noticias", Folia Humanística, 2, dedicado a Ramón Menéndez Pidal, 1964, págs. 589-594.

130. "La lengua de la poesía épica en los cantares de gesta y en el Romancero viejo", Anuario de Letras de México, IV, 1964, págs. 5-24. (Reimpreso en De la Edad Media a nuestros días, Madrid, Gredos, 1967, págs. 9-28. También, con el título de "Tiempos verbales y modos narrativos en los cantares de gesta y en el Romancero viejo", en Historia y crítica de la literatura española. I Edad Media, Barcelona, Crítica, 1979, págs. 274-277).

131. "El tema de la muerte en el Libro de Buen Amor", Estudios dedicados a James Homer Herriott, Universidad de Wisconsin, 1966, págs. 127-144. (Reimpreso en Actas del Segundo Congreso Internacional de Hispanistas, Nimega, 1967, págs, 73-91; y en De la Edad Media a nuestros días, Madrid, Gredos, 1967, págs. 53-75).

132. “Amor cortés o parodia? A propósito de la primitiva lírica de Castilla”, Estudis de llatí medieval $i$ de filologia romànica dedicats a la memòria de Lluís Nicolau d'Olwer. II Estudis Romànics, IX, 1961-1966, págs. 11-14. (Reimpreso en De la Edad Media a nuestros días, Madrid, Gredos, 1967, págs. 48-52). 
133. "Un ejemplo de prosa retórica a fines del siglo XIV: los Soliloquios de Fray Pedro Fernández Pecha”, Studies in Honor of Lloyd A. Kasten, University of Wisconsin Press, 1975, págs. 117-128. (Reimpreso en Poetas y prosistas de ayer y de hoy, Madrid, Gredos, 1977, págs. 9-24).

134. "Sobre el Cantar de Mio Cid. Crítica de críticas. Cuestiones lingüísticas", Études de Philologie Romane et d'Histoire Littéraire offerts à Jules Horrent, Liège, J.M. D’Heur, N. Cherubini, 1980, págs. 213-231. (Reimpreso en Francisco Marcos Marín (coord.), Introducción plural a la gramática histórica, Madrid, Cincel, 1983, págs. 239-258. También en Estudios de historia lingüística española, Madrid, Paraninfo, 1985, págs. 11-31).

135. "Símbolos y palabras en el Setenario de Alfonso X", NRFH, 29, In memoriam Raimundo Lida, 1980, págs. 247-261. (Reimpreso en Estudios de historia lingüística española, Madrid, Paraninfo, 1985, págs. 226-238. También en Léxico e historia. I. Palabras, Madrid, Istmo, 1992, págs. 115-134).

136. "Sobre el Cantar de Mio Cid. Crítica de críticas. Cuestiones históricas", Essays on Narrative Fiction in the Iberian Peninsula in Honour of Frank Pierce, Oxford, The Dolphin Book Co. Ltd., 1982, págs. 55-66. (Reimpreso en Estudios de historia lingüística española, Madrid, Paraninfo, 1985, págs. 32-42).

137. "Mozárabe y catalán o gascón en el Auto de los Reyes Magos", Miscel-lània Aramon $i$ Serra, III, Barcelona, Curial, 1983, págs. 227-294. (Reimpreso en Estudios de historia lingüística española, Madrid, Paraninfo, 1985, págs. 138-156).

138. "Las rimas penitenciarias del Canciller Ayala. Tradición y elemento personal", Homenaje a Pedro Sáinz Rodríguez, II, Madrid, Fundación Universitaria Española, 1986, págs. 391-403. (Reproducido en De Ayala a Ayala. Estudios literarios y estilísticos, Madrid, Istmo, 1988, págs. 39-54).

139. "Gonzalo de Berceo y Joan Roiç de Corella ante el Duelo de la Virgen", Miscel-lània d'homenatge al Dr. Esteve Pujals, Barcelona, Columna, 1994, págs. 174-187. (Reproducido en De Berceo a Jorge Guillén. Estudios literarios, Madrid, Gredos, 1997, págs. 9-20).

Véase también 266, 278, 292, 300, 310, 314 y 440.

\section{Historia LITERARIA: SIGLO XV}

140. "Un viajero por la España de los Reyes Católicos", Cuadernos Hispanoamericanos, 20, 1951, págs, 310-311.

141. "La lengua de la poesía lírica desde Macías hasta Villasandino", Romance Philology, VII, 1953, págs, 51-59. (Reimpreso en Estudios de historia lingüística española, Madrid, Paraninfo, 1985, págs. 239-248).

142. "Notas sobre Micer Francisco Imperial", NRFH, VII, 1953, Homenaje a Amado Alonso, págs. 337-351. (Reimpreso en De la Edad Media a nuestros días, Madrid, Gredos, 1967, págs. 76-94).

143. "Sobre la fecha de la Comedieta de Ponza", Archivum, IV, 1954, págs. 81-86.

144. "La cultura literaria activa en la poesía juvenil de Santillana", Atlante, 1954, 2, 3, págs. 119-125. 
145. "El lenguaje del Amadís manuscrito", BRAE, XXXVI, 1956, págs. 409-416.

146. "El lenguaje del Amadís manuscrito", en A. Rodríguez Moñino, A. Millares Carlos y R. Lapesa, El primer manuscrito del Amadís de Gaula, Madrid, Imprenta de Silverio Aguirre Torre, 1957.

147. "El endecasílabo en los sonetos de Santillana", Romance Philology, X, 1957, págs. 180-185.

148. "Un gran poema estoico del Marqués de Santillana”, Ínsula, XII, 130, 1957, págs. 1-2.

149. "Los Proverbios de Santillana. Contribución al estudio de sus fuentes", Hispanófila, I, 1957, págs. 5-19. (Reimpreso en De la Edad Media a nuestros días, Madrid, Gredos, 1967, págs. 95-122).

150. La obra literaria del Marqués de Santillana, Madrid, Ínsula, 1957, 348 págs.

151. "El elemento moral en el Laberinto de Mena: su influjo en la disposición de la obra", Hispanic Review, XXVII, 1959, págs. 257-266.

152. “Los endecasílabos de Imperial”, Miscelánea Filológica dedicada a Mons. A. Griera, II, S. Cugat del Vallés-Barcelona, Instituto Internacional de Cultura Románica, 1960, págs. 26-47.

153. "Sobre Juan de Lucena: escritos suyos mal conocidos o inéditos", Collected Studies in honor of Américo Castro's Eightieth Year, Oxford, The Lincombe Lodge Research Library, 1965, págs. 275-290. (Reimpreso en De la Edad Media a nuestros días, Madrid, Gredos, 1967, págs. 123-144).

154. "Sobre la Coronación de Mossén Jordi de Sant Jordi: Venus y los elefantes", Estudis de literatura oferts a Jordi Rubió i Balaguer, Estudis Romànics, X, 1962-1967, págs. 273-281.

155. "La Celestina en la obra de Américo Castro", Estudios sobre la obra de Américo Castro, Madrid, Taurus, 1971, págs. 229-261. (Reimpreso en Poetas y prosistas de ayer y de hoy, Madrid, Gredos, 1977, págs. 60-72).

156. "En torno a un monólogo de Calisto", Homenaje a Aranguren, Revista de Occidente, 1972, págs. 213-228. (Reimpreso en El comentario de textos, Madrid, Castalia, 1973, págs. 30-51. También en Poetas y prosistas de ayer y de hoy, Madrid, Gredos, 1977, págs. 73-91).

157. "De nuevo sobre las serranillas de Santillana", Libro-homenaje a Antonio Pérez Gómez, II, Cieza, La fonte que mana y corre..., 1978, págs. 43-50.

158. "Poesía docta y afectividad en las Consolatorias de Gómez Manrique", Estudios sobre literatura y arte dedicados al profesor Emilio Orozco Díaz, II, Granada, Universidad de Granada, 1979, págs. 231-239. (Reimpreso en De Ayala a Ayala. Estudios literarios y estilísticos, Madrid, Istmo, 1988, págs. 55-64).

159. "Las serranillas del Marqués de Santillana", Historia y crítica de la literatura española. I Edad Media, Barcelona, Crítica, 1979, págs. 320-325. Recoge las páginas 52-59 y 61-63 de La obra literaria del Marqués de Santillana, Madrid, Ínsula, 1957).

160. "Las serranillas del Marqués de Santillana”, en Manuel Alvar (coord.) El comentario de textos. 4. La poesía medieval, Madrid, Castalia, 1983, págs. 243276. (Publicado también en De Berceo a Jorge Guillén. Estudios literarios, Madrid, Gredos, 1997, págs. 21-54). 
161. "Cartas y dezires o lamentaciones de amor: desde Santillana y Mena hasta don Diego Hurtado de Mendoza", Symbolae Pisanae. Studi in honore di Guido Mancini, I, Pisa, Giardini Editori, 1989, págs. 295-310. (Publicado también en De Berceo a Jorge Guillén. Estudios literarios, Madrid, Gredos, 1997, págs. 78-97).

162. "El vivir problemático en La Celestina", Doctorado honoris causa de los Excmos. Sres. D. Emilio Alarcos Llorach, D. Manuel Alvar López y D. Rafael Lapesa Melgar, Valladolid, Universidad de Valladolid, 1990, págs. 4955. (Publicado también en De Berceo a Jorge Guillén. Estudios literarios, Madrid, Gredos, 1997, págs. 98-109).

163. "Apostillas a la Comedieta de Ponza", en "Busquemos otros montes y otros ríos". Estudios de literatura española del Siglo de Oro dedicados a Elías L. Rivers, Madrid, Castalia, 1992, págs. 147-153. (Reproducido en De Berceo a Jorge Guillén. Estudios literarios, Madrid, Gredos, 1997, págs. 55-63).

Véase también 139, 190, 273, 274, 296, 318 y 320.

\section{HISTORIA LITERARIA: SIGLO XVI}

164. "La Vida de san Ignacio del P. Ribadeneyra, RFE, XXI, 1934, págs. 30-50. (Reimpreso en De la Edad Media a nuestros días, Madrid, Gredos, 1967, págs. 193-211).

165. "Tres sonetos inéditos de Cetina y una atribución falsa", RFE, XXIV, 1937, págs. $380-383$.

166. "La poesía de Gutierre de Cetina", Hommage à Ernest Martinenche. Études Hispaniques et Américaines, Paris, Éditions d'Artrey, s.a. [1939-1940], págs. 248-261.

167. "El mundo simbólico de San Juan de la Cruz", La Voz de Asturias, Oviedo, 10 de mayo de 1942.

168. La trayectoria poética de Garcilaso, Madrid, Revista de Occidente, 1948, 242 págs.

169. “Gutierre de Cetina. Disquisiciones biográficas”, Estudios Hispánicos. Homenaje a Archer M. Huntington, Wellesley, Mass. 1952, págs, 311-326.

170. "Las odas de Fray Luis de León a Felipe Ruiz", Studia Philologica. Homenaje a Dámaso Alonso, II, Madrid, Gredos, 1961, págs. 301-318. (Reimpreso en De la Edad Media a nuestros días, Madrid, Gredos, 1967, págs. 172-192).

171. "Poesía de cancionero y poesía italianizante", Stenae. Estudios de Filología e Historia dedicados al profesor Manuel García Blanco, Acta Salmanticensia. Filosofía y Letras, XVI, 1962, págs. 259-279. (Reimpreso en De la Edad Media a nuestros días, Madrid, Gredos, 1967, págs. 145-171; también en Estudios lingüísticos, literarios y estilísticos, Valencia, Universitat de València, 1987, págs. 73-93).

172. "Garcilaso de la Vega en el pórtico del Renacimiento español”, II Curso Internacional de Cultura Románica, Memoria, Puigcerdá, 1966, págs. 27-40. 
173. "Más sobre atribuciones a Gutierre de Cetina: I) poemas del ms. B.N. 3.902; II) a la anacreóntica", Homenaje al Profesor Alarcos García, Universidad de Valladolid, 1965-1967, págs. 275-280.

174. La trayectoria poética de Garcilaso, $2^{\mathrm{a}}$ ed., Madrid, Revista de Occidente, 1968, 234 págs.

175. "Latinismos semánticos en la poesía de Fray Luis de León”, Homenaje a Anonio Tovar, Madrid, Gredos, 1972, págs. 243-251. (Reimpreso en Léxico e historia. I. Palabras, Madrid, Istmo, 1992, págs. 153-165).

176. "El cultismo semántico en la poesía de Garcilaso", Revista de Estudios Hispánicos, Homenaje a Margot Arce, II, 1972, págs. 33-45. (Reimpreso en Poetas y prosistas de ayer y de hoy, Madrid, Gredos, 1977, págs. 92-109. También en Garcilaso: estudios completos, Madrid, Istmo, 1985, págs. 239-254; y en Léxico e historia. I. Palabras, Madrid, Istmo, 1992, págs. 135-151).

177. "El hipérbaton en la poesía de Fray Luis de León", Studies in Spanish Literature of the Golden Age presented to Edward M. Wilson, London, 1973, págs. 137-147.

178. "El cultismo en la poesía de Fray Luis de León”, Atti del Convegno Internazionale sul tema: Premarinismo e Pregongorismo, Roma, Accademia Nazionale dei Lincei, 1973, págs. 301-318. (Reimpreso en Poetas y prosistas de ayer y de hoy, Madrid, Gredos, 1977, págs. 110-145).

179. "Sobre algunos sonetos de Garcilaso", en Elías L. Rivers (ed.), La poesía de Garcilaso: ensayos críticos, Barcelona, Ariel, 1974, págs. 91-102.

180. "Garcilaso y Fray Luis de León: coincidencias temáticas y contraste de actitudes", Archivum, XXVI, Homenaje a la memoria de Carlos Clavería, 1976, págs. 7-17. (Publicado con ampliaciones en Poetas y prosistas de ayer y de hoy, Madrid, Gredos, 1977, págs. 146-177).

181. "La trayectoria poética de Garcilaso", en Historia y crítica de la literatura española. II. Siglos de Oro: Renacimiento, Barcelona, Crítica, 1980, págs. 127131. Reproduce las págs. 175-184 de La trayectoria poética de Garcilaso, $2^{\mathrm{a}}$ ed., Madrid, Revista de Occidente, 1968).

182. "Castillejo y Cetina. Entre poesía de cancionero y poesía italianizante", en Historia y crítica de la literatura española. II. Siglos de Oro: Renacimiento, Barcelona, Crítica, 1980, págs. 149-155. Reproduce las págs. 145-171 de "Poesía de cancionero y poesía italianizante", Stenae. Estudios de Filología e Historia dedicados al profesor Manuel García Blanco, Acta Salmanticensia. Filosofía y Letras, XVI, 1962).

183. "La odas de Fray Luis de León a Felipe Ruiz", en Historia y crítica de la literatura española. II. Siglos de Oro: Renacimiento, Barcelona, Crítica, 1980, págs. 399-405. Reproduce las págs. 173-178, 181-183 y 189-192 del trabajo del mismo título, en De la Edad Media a nuestros días, Madrid, Gredos, 1967).

184. "Tradición literaria de un poema teresiano", Anales de literatura hispanoamericana, 9, Homenaje a Francisco Sánchez Castañer, 1980, págs. 307-314. (Reimpreso en De Ayala a Ayala. Estudios literarios y estilísticos, Madrid, Istmo, 1988, págs. 141-149). 
185. "Un Calisto o Romeo anónimo del siglo XVI”, Letras, 6-7, Homenaje a Ángel Battistessa, 1982-1983, págs. 117-118. (Reimpreso en De Ayala a Ayala. Estudios literarios y estilísticos, Madrid, Istmo, 1988, págs. 81-82).

186. "Estilo y lenguaje de Santa Teresa en las Exclamaciones del alma a su Dios", Aureum Saeculum Hispanum: beiträge zu texten des Siglo de Oro, Festschrift für Hans Flasche 70, Wiesbaden, Franz Steiner, 1983, págs. 125-140. (Reimpreso en De Ayala a Ayala. Estudios literarios y estilísticos, Madrid, Istmo, 1988, págs. 151-168).

187. La trayectoria poética de Garcilaso, Madrid, Alianza Editorial, 1985. (Reproduce fotográficamente la edición de 1968).

188. Garcilaso: estudios completos, Madrid, Istmo, 1985, 266 págs.

189. "Enfados y contentos en la poesía española del siglo XVI”, Filología, XX, 2, Homenaje a Raimundo Lida, 1985, págs. 75-109. (Reimpreso en De Ayala a Ayala. Estudios literarios y estilísticos, Madrid, Istmo, 1988, págs. 105-140).

190. "Sobre el mito de Narciso en la lírica medieval y renacentista", Libro homenaje a D. Aurelio Miró Quesada Sosa, Lima, P.L. Villanueva, 1987, págs. 543553. (Publicado también en Epos, IV, 1988, págs. 9-19; y en De Berceo a Jorge Guillén. Estudios literarios, Madrid, Gredos, 1997, págs. 64-77).

191. “La Égloga II de Garcilaso", Estudios lingüísticos, literarios y estilísticos, Valencia, Universitat de València, 1987, págs. 97-111. (Reproduce el capítulo del mismo nombre de La trayectoria poética de Garcilaso, $2^{\mathrm{a}}$ ed., Madrid, Revista de Occidente, 1968).

192. "Los géneros líricos del Renacimiento: la herencia cancioneresca", Homenaje a Eugenio Asensio, Madrid, Gredos, 1988, págs. 259-275. (Publicado también en De Berceo a Jorge Guillén. Estudios literarios, Madrid, Gredos, 1997, págs. 122-145).

193. "Los poemas de Herrera en metros castellanos", Dicenda. Cuadernos de filología hispánica, 7, Arcadia. Estudios y textos dedicados a Francisco López Estrada, II, 1988, págs. 191-211. (Publicado también en De Berceo a Jorge Guillén. Estudios literarios, Madrid, Gredos, 1997, págs. 146-173).

194. "El Diálogo de la lengua”, De Ayala a Ayala. Estudios literarios y estilísticos, Madrid, Istmo, 1988, págs. 65-79. [Reproduce el prólogo de su edición del Diálogo de la lengua, en Clásicos Ebro, de 1940].

195. "La descendencia hispano-portuguesa de una canción petrarquesca: de Garcilaso a Camõens y Cervantes", De Ayala a Ayala. Estudios literarios y estilísticos, Madrid, Istmo, 1988, págs. 83-104. (Reimpreso en Homenaje a Alonso Zamora Vicente, III, tomo 2, Madrid, Castalia, 1992, págs. 131-148).

196. "Garcilaso de la Vega", Siete siglos de autores españoles, Kassel, Edition Reichenberger, 1991, págs. 47-51.

197. Estudio preliminar a Garcilaso de la Vega, Obra poética y textos en prosa, edición, prólogo y notas de Bienvenido Morros, Barcelona, Crítica, 1995.

Véase también 53, 161 y 267. 


\section{XII: HISTORIA LITERARIA: SIGLO XVII}

198. "La Jerusalén de Tasso y la de Lope", BRAE, XXV, 1946, págs. 111-136. (Reimpreso en De la Edad Media a nuestros días, Madrid, Gredos, 1967, págs. 264-285).

199. “Aldonza-Dulce-Dulcinea”, Boletín de la Biblioteca Menéndez Pelayo, XXIII, 1947, págs. 48-53. (Reimpreso en De la Edad Media a nuestros días, Madrid, Gredos, 1967, págs. 212-218. También en Léxico e historia. I. Palabras, Madrid, Istmo, 1992, págs. 191-198).

200. "El lentiscar de Cartagena", Ínsula, V, 52, 1950. (Reimpreso en De la Edad Media a nuestros días, Madrid, Gredos, 1967, págs. 286-289).

201. "En torno a La Española Inglesa y el Persiles", Homenaje a Cervantes, II. Estudios cervantinos, Valencia, Mediterráneo, 1950, págs. 365-388. (Reimpreso en De la Edad Media a nuestros días, Madrid, Gredos, 1967, págs. 242263).

202. "Góngora y Cervantes: coincidencias de temas y contraste de actitudes", Revista Hispánica Moderna, XXXI, 1965, Homenaje a Ángel del Río, págs. 247263. (Reimpreso en De la Edad Media a nuestros días, Madrid, Gredos, 1967, págs. 219-241).

203. "El sustantivo sin actualizador en las Soledades gongorinas", Cuadernos Hispanoamericanos, Homenaje a Dámaso Alonso, 1973, págs. 433-448. (Reimpreso con el título de "Lenguaje normal y lenguaje poético: El sustantivo sin actualizador en las Soledades gongorinas" en Poetas y prosistas de ayer y de hoy, Madrid, Gredos, 1977, págs. 186-209. También en Estudios lingüísticos, literarios y estilísticos, Valencia, Universitat de València, 1987, págs. 115-128; y en Estudios de morfosintaxis histórica del español, Madrid, Gredos, 2000, págs. 455-474).

204. "Presencia de Fray Luis en el soneto de Lope ¿Qué tengo yo que mi amistad procuras?", Homenaje a Don Agustín Millares Carlo, Caja Insular de Ahorros de Gran Canaria, II, 1975, págs. 699-703. (Reimpreso en Poetas y prosistas de ayer y de hoy, Madrid, Gredos, 1977, págs. 178-185).

205. "Consideraciones sobre La vida es sueño", BRAE, LXII, 1982, págs. 87-102. (Reproducido en De Ayala a Ayala. Estudios literarios y estilísticos, Madrid, Istmo, 1988, págs. 227-241).

206. "La Jerusalén conquistada", en Historia y crítica de la literatura española. III. Siglos de Oro: Barroco, Barcelona, Crítica, 1983, págs. 169-173. Reproduce las págs. 271-275 y 280-284 de "La Jerusalén de Tasso y la de Lope", De la Edad Media a nuestros días, Madrid, Gredos, 1967).

207. “Lenguaje y estilo de Calderón”, Calderón. Actas del Congreso Internacional sobre Calderón y el teatro español del Siglo de Oro, Madrid, CSIC, 1983, págs. 51-101. (Reproducido en De Ayala a Ayala. Estudios literarios y estilísticos, Madrid, Istmo, 1988, págs. 169-225).

208. "Poesía lírica del Siglo de Oro: los géneros". Boletín Informativo. Fundación Juan March, 159, mayo de 1986, págs. 35-40. [Resumen de tres conferencias dadas en dicha Fundación en el mes de febrero de 1986]. 
209. "Calderón trágico", Historia y crítica de la literatura española. III. Tomo 2, Siglos de Oro. Barroco, primer suplemento, Barcelona, Crítica, 1992, págs. 430-435. (En colaboración con Francisco Ruiz Ramón).

210. "Comentario al capítulo V de la segunda parte del Quijote", Actas del Tercer Coloquio Internacional de la Asociación de Cervantinistas. Alcalá de Henares, 1990, Madrid, Dirección General de Relaciones Culturales y Científicas, Ministerio de Asuntos Exteriores; Barcelona, Anthropos, 1993, págs. 11-21. (Publicado también en De Berceo a Jorge Guillén. Estudios literarios, Madrid, Gredos, 1997, págs. 174-190).

211. “Comentario lingüístico y literario de El Criticón”, Cuaderno gris, 1995, n 1 , págs. 165-177 [dedicado a Gracián]. (También en Cuaderno gris, 2002, no 1 , págs. 159-170 [dedicado a Gracián hoy: la intemporalidad de un clásico].

Véase también 271, 293, 311 y 316.

XIII. HiSTORIA LITERARIA: SIGLO XVIII

212. "Sobre el estilo de Feijoo", Mélanges à la mémoire de Jean Sarrailh, II, París, Institut d'Études Hispaniques, 1966, págs. 300-310. (Reimpreso en De la Edad Media a nuestros días, Madrid, Gredos, 1967, págs. 290-299).

213. "El problema de la lengua en Feijoo", Boletín de la Real Academia Gallega, LXIX, 358, 1976, págs. 65-68.

214. "Sobre el problema de la lengua en Feijoo y las peculiaridades de su estilo", El español moderno y contemporáneo. Estudios lingüísticos, Barcelona, Crítica, 1996, págs. 43-54.

215. “Comentario a la Elegía a las musas de Leandro Moratín”, Sin fronteras. Homenaje a María Josefa Canellada, Madrid, Editorial Complutense, 1994, págs. 319-328. (Publicado también en De Berceo a Jorge Guillén. Estudios literarios, Madrid, Gredos, 1997, págs. 191-200).

Véase también 325.

XIV. HISTORIA LITERARIA: SigLO XIX

216. “Bécquer, Rosalía y Machado”, Ínsula, IX, 100-101, 1954. (Reimpreso en De la Edad Media a nuestros días, Madrid, Gredos, 1967, págs. 300-306).

217. "El beodo frente al literato en San Agustín y en Larra", Poemas y ensayos para un homenaje [En memoria de Phillys Burrows Turnbull], Madrid, Tecnos, 1976, págs. 120-127. (Reimpreso en Poetas y prosistas de ayer y de hoy, Madrid, Gredos, 1977, págs. 220-229).

218. "Tres poetas ante la soledad: Bécquer, Rosalía y Machado", Essays on Hispanic Literature in Honor of Edmund L. King, London, Tamesis Books, 1983, págs. 151-173. (Publicado también por el Departamento de Lingüística General de la UNED, Madrid, 1983, 34 págs. También en Estudios lingüísticos, 
literarios y estilísticos, Valencia, Universitat de València, 1987, págs. 131152; y en De Ayala a Ayala. Estudios literarios y estilísticos, Madrid, Istmo, 1988, págs. 243-272).

219. "El lenguaje literario en los años de Larra y Espronceda", Homenaje a Julián Marías, Madrid, Espasa-Calpe, 1984, págs. 347-379. (Reproducido en El español moderno y contemporáneo. Estudios lingüísticos, Barcelona, Crítica, 1996, págs. 67-110).

220. "Libertad, Igualdad, Fraternidad: devaluación y revaloración de las palabras", Historia y crítica de la literatura española. V, tomo 2. Romanticismo y Realismo, Barcelona, Crítica, 1994, págs. 113-117.

Véase también 93, 94, 281, 288, 294 y 299.

\section{HISTORIA LITERARIA: SIGLO XX}

221. "Borges en Madrid", Revista de Occidente, 4, 1963, págs. 109-112.

222. "Para rendir homenaje" [a Azorín], Revista de Occidente, 4, 1963, pág. 74.

223. "Abril y La casa encendida”, Cuadernos Hispanoamericanos, 257-258, 1971, Homenaje a Luis Rosales, págs. 451-460. (Reimpreso con el título de "Abril y La casa encendida de Luis Rosales" en Poetas y prosistas de ayer y de hoy, Madrid, Gredos, 1977, págs. 385-414).

224. "Sobre algunos símbolos en la poesía de Antonio Machado", Cuadernos Hispanoamericanos, 304-307, octubre-diciembre de 1975 y enero de 1976, I, págs. 386-431. (Reimpreso en Poetas y prosistas de ayer y de hoy, Madrid, Gredos, 1977, págs. 235-299).

225. "Símbolos en la poesía de Antonio Machado", Antonio Machado y Soria, Soria, Patronato José María Quadrado, CSIC, Centro de Estudios Sorianos, 1976, págs. 116-128.

226. "Las Últimas lamentaciones y la Muerte de Abel Martín de Antonio Machado", Estudios de lingüística textual. Homenaje al profesor Muñoz Cortés, Murcia, Universidad de Murcia, 1976, págs. 313-332. (Reimpreso en Poetas y prosistas de ayer y de hoy, Madrid, Gredos, 1977, págs. 300-327).

227. "Aleixandre canta para todos", Ínsula, 374-375, enero-febrero, 1978.

228. "El sustantivo esencial en la poesía de Jorge Guillén", Homenaje a Jorge Guillén, Wellesley, Massachussets, 1978, págs. 303-314. (Versión ampliada en Comentarios lingüísticos de textos, Valladolid, Universidad de Valladolid, 1979, págs. 189-203. También en De Ayala a Ayala. Estudios literarios y estilísticos, Madrid, Istmo, 1988, págs. 281-294).

229. “Amor y muerte en tres poemas de Antonio Machado (1903-1907), Homenaje a Antonio Sánchez Barbudo. Ensayos de literatura española moderna, Madison, University of Wisconsin, 1981, págs. 81-87. (Reimpreso en De Ayala a Ayala. Estudios literarios y estilísticos, Madrid, Istmo, 1988, págs. 273-279).

230. "La poesía encendida de Luis Rosales", en Historia y crítica de la literatura española. VIII. Época contemporánea (1939-1980), Barcelona, Crítica, 1981, págs. 180-188. Reproduce las págs. 391-413 de "Abril y La casa encen- 
dida”, Cuadernos Hispanoamericanos, 257-258, 1971, Homenaje a Luis Rosales.

231. "A propósito de Recuerdos y olvidos de Francisco Ayala" [Palabras pronunciadas en la presentación del libro de este título en la Biblioteca Nacional de España, Madrid, 5 de mayo de 1982], Cuenta y razón del pensamiento actual, 7, verano 1982, págs. 171-174. (Reproducido en De Ayala a Ayala. Estudios literarios y estilísticos, Madrid, Istmo, 1988, págs. 333-340).

232. "La evolución poética de Vicente Aleixandre", Homenaje a José Manuel Blecua, Madrid, Gredos, 1983, págs. 307-323. (Reproducido en De Ayala a Ayala. Estudios literarios y estilísticos, Madrid, Istmo, 1988, págs. 295-314).

233. "XX aniversario del fallecimiento de Azorín", Monóvar. Revista de la Asociación Cultural de Estudios Monoveneros, 6, diciembre de 1987, pág. 1. [Reproduce, ampliado, "Para rendir homenaje" [a Azorín], Revista de Occidente, 4, 1963, pág. 74].

234. "Juan Ramón Jiménez. De la lira franciscana al niñodiós de Moguer", Acto solemne de investidura como doctor honoris causa, Sevilla, Universidad de Sevilla, 28 de mayo de 1991, págs. 13-38.

235. "El legado poético de Juan Ramón Jiménez", en Ann L. Mackenzie y Dorothy Severin (eds.), Hispanic Studies in Honour of Geoffrey Ribbans, Liverpool, Liverpool University Press, 1992, págs. 223-246. (Reproducido en El legado cultural de España al siglo XXI. 2. La literatura: clásicos contemporáneos, Barcelona, Colegio Libre de Eméritos-Círculo de Lectores, 1992, págs. 171204. También en De Berceo a Jorge Guillén. Estudios literarios, Madrid, Gredos, 1997, págs. 201-237).

236. "En torno a Lugar de Lázaro y Huerto de Melibea. La estructura simétrica de ...que van a dar en la mar", Ínsula, 554-555, febrero-marzo, 1993. (Reproducido en De Berceo a Jorge Guillén. Estudios literarios, Madrid, Gredos, 1997, págs. 275-287).

Véase también 216, 218, 269, 275, 295, 333, 338, 445, 446 y 447.

XVI. EDICIÓN DE TEXTOS DE LA LITERATURA ESPAÑOLA

237. Juan de Valdés, Diálogo de la lengua, selección, estudio y notas por Rafael Lapesa, primera edición ilustrada, Zaragoza, Editorial Ebro, 1940, 136 págs.

238. Juan de Valdés, Diálogo de la lengua, selección, estudio y notas por Rafael Lapesa, segunda edición ilustrada, Zaragoza, Editorial Ebro, 1946.

239. Poetas del siglo XVI. Período clásico (1525-1590), selección, estudio y notas por Rafael Lapesa, Barcelona, Editorial Rauter, Biblioteca Hispania, t. 3, 1947, 220 págs.

240. Juan de Valdés, Diálogo de la lengua, selección, estudio y notas por Rafael Lapesa, tercera edición ilustrada, Zaragoza, Editorial Ebro, 1954.

241. Romancero tradicional de las lenguas hispánicas (español, portugués, catalán, sefardí), colección de textos y notas de María Goyri y Ramón Menéndez Pidal. I. Ramón Menéndez Pidal, Romanceros del Rey Rodrigo y de Bernar- 
do del Carpio, edición y estudios a cargo de R. Lapesa, D. Catalán, A. Galmés, J. Caso, Madrid, Seminario Menéndez Pidal, Gredos, 1957.

242. Íñigo López de Mendoza, Marqués de Santillana, Serranillas, edición y prólogo de Rafael Lapesa, Santander, s.a. [1958], 36 págs.

243. Juan de Valdés, Diálogo de la lengua, selección, estudio y notas por Rafael Lapesa, cuarta edición ilustrada, Zaragoza, Editorial Ebro, 1960.

244. Juan de Valdés, Diálogo de la lengua, selección, estudio y notas por Rafael Lapesa, quinta edición ilustrada, Zaragoza, Editorial Ebro, 1965.

245. Juan de Valdés, Diálogo de la lengua, selección, estudio y notas por Rafael Lapesa, sexta edición ilustrada, Zaragoza, Editorial Ebro, 1974.

246. Juan de Valdés, Diálogo de la lengua, edición de Rafael Lapesa (preparada y dispuesta para la imprenta por $\mathrm{M}^{\mathrm{a}}$ Teresa Echenique y Mariano de la Campa). Trabajos introductorios de $\mathrm{M}^{\mathrm{a}}$ José Martínez Alcalde, Mariano de la Campa Gutiérrez, Fco. Javier Satorre Grau y $\mathrm{M}^{\mathrm{a}}$ Teresa Echenique Elizondo, Valencia, Tirant lo Blanc, 2008.

XVII. EDICIÓN DE OBRAS AJENAS

247. Amado Alonso, De la pronunciación medieval a la moderna en español, tomo I, ultimado y dispuesto para la imprenta por Rafael Lapesa, Madrid, Gredos, 1955.

248. Ramón Menéndez Pidal, con la colaboración del Centro de Estudios Históricos, Crestomatía del español medieval, acabada y revisada por Rafael Lapesa y María Soledad de Andrés, tomo I, Madrid, Seminario Menéndez Pidal y Editorial Gredos, 1965; tomo II, 1966.

249. Amado Alonso, De la pronunciación medieval a la moderna en español, tomo I, $2^{\text {a }}$ edición, ultimado y dispuesto para la imprenta por Rafael Lapesa, Madrid, Gredos, 1967.

250. Amado Alonso, De la pronunciación medieval a la moderna en español, tomo II, ultimado y dispuesto para la imprenta por Rafael Lapesa, Madrid, Gredos, 1969.

251. Ramón Menéndez Pidal, con la colaboración del Centro de Estudios Históricos, Crestomatía del español medieval, acabada y revisada por Rafael Lapesa y María Soledad de Andrés, $2^{\mathrm{a}}$ edición, tomo I, Madrid, Seminario Menéndez Pidal y Editorial Gredos, 1971; tomo II, 1976.

252. Américo Castro, Sobre el nombre y el quién de los españoles, edición al cuidado de Rafael Lapesa, Madrid, Sarpe, 1985.

\section{RESEÑAS}

253. García Blanco, M., Dialectalismos leoneses de un códice del Fuero Juzgo, en RFE, XVI, 1929, págs. 280-281.

254. Fernández Llera, V. Gramática y vocabulario del Fuero Juzgo, en RFE, XVII, 1930, págs. 295-296. 
255. Richardson, H.B., An Etymological Vocabulary to the "Libro de Buen Amor", en RFE, XVIII, 1931, págs. 56-58. (Reimpresa en Léxico e historia. I. Palabras, Madrid, Istmo, 1992, págs. 27-30).

256. Schultze-Jahde, K., Ausdrückswerk und stilbegriff, en Boletín Bibliográfico del Centro de Intercambio Intelectual Germano-Español, IV, 1931, págs. 32-34.

257. Braue, A., Beiträge zur Satzgestaltung der spanischen Umgangssprache, en RFE, XX, 1933, págs. 296-297.

258. Montesino, Fr. A., Coplas sobre diversas devociones y misterios de nuestra santa fe católica, y Comendador Román, Coplas de la Pasión con la Resurrección, en RFE, XXIV, 1937, págs. 94-96.

259. Agostini, E. y Gallego, R., Itinerarios y pasajes cervantinos, en RFE, XXIV, 1937, pág. 98.

260. Ringenson, K., Le rapport d'ordinaux et de cardinaux dans les expressions de la date dans les langues romanes, en RFE, XXIV, 1937, págs. 229-231. (Reimpresa en Estudios de morfosintaxis histórica del español, Madrid, Gredos, 2000, págs. 892-895).

261. Saavedra Molina, J., Los hexámetros castellanos y en particular los de Rubén Dario, en RFE, XXIV, 1937, págs. 232-233.

262. Cossío, J.M. de, Notas y estudios de crítica literaria. Poesía española. Notas de asedio, en RFE, XXIV, 1937, págs. 405-406.

263. Sahlin, M., Étude su la carole médiévale. L'origine du mot et ses rapports avec l'Église, en RFE, XXV, 1941, págs. 122-124. (Reimpresa en Léxico e historia. I. Palabras, Madrid, Istmo, 1992, págs. 41-44).

264. Gili Gaya, S., Curso superior de sintaxis española, en Insula, I, marzo de 1946, pág. 8. (Reimpresa en Estudios de morfosintaxis histórica del español, Madrid, Gredos, 2000, págs. 889-891).

265. Américo Castro, España en su historia. Cristianos, moros y judíos, en NRFH, III, 1949, págs. 294-307. (Publicado con el título de "Sobre España en su Historia de Américo Castro" en Poetas y prosistas de ayer y de hoy, Madrid, Gredos, 1977, págs. 328-352).

266. Menéndez Pidal, R., La epopeya castellana a través de la literatura española, en NRFH, 1949, págs. 396-398.

267. Alcalá, M., "Del virgilianismo de Garcilaso de la Vega", y Arrando, M.P., Auzías March y Garcilaso de la Vega, poetas del dolorido amar, en Hispanic Review, XVIII, 1950, págs. 87-88.

268. Menéndez Pidal, R., El Imperio Hispánico y los cinco reinos, en Cuadernos Hispanoamericanos, 16, 1950, págs. 117-121.

269. "Un estudio estilístico", [sobre Amado Alonso, Poesía y estilo de Pablo Neruda], en Ínsula, VII, 79, 1952.

270. Casares J., Introducción a la lexicografía moderna, en Lingua, 3, 1952, págs. 421-425. (Reimpreso en Léxico e historia. II. Diccionarios, Madrid, Istmo, 1992, págs. 93-98).

271. Green, O., Courtly Love in Quevedo, en Hispanic Review, XXI, 1953, págs. 237-243. (Publicado con el título de "El amor cortés en Quevedo" en Poetas y prosistas de ayer y de hoy, Madrid, Gredos, 1977, págs. 210-219). 
272. "Un palacio de la época imperial”, [sobre I. Calandre, El Palacio del Pardo (Enrique III-Carlos III)], en Cuadernos Hispanoamericanos, XVII, 1953, págs. 245-246.

273. Lida de Malkiel, M.R., Juan de Mena, poeta del Prerrenacimiento español, en NRFH, IX, 1955, págs. 161-167.

274. Lida de Malkiel, M.R., La originalidad artística de 'La Celestina', Romance Philology, 1963, María Rosa Lida de Malkiel Memorial, págs. 55-74. (Reimpreso en Poetas y prosistas de ayer y de hoy, Madrid, Gredos, 1977, págs. 25-59).

275. "Un nuevo libro de Jorge Guillén" [sobre Jorge Guillén, Y otros poemas], Ínsula, XXIX, 336, 1974. (Reimpreso en Poetas y prosistas de ayer y de hoy, Madrid, Gredos, 1977, págs. 362-369).

276. “Aurelio Miró Quesada y su reciente libro sobre Mariano Melgar”, Nueva Estafeta, 5, abril 1979, págs. 76-77.

277. "Un vademécum indispensable" [sobre Manuel Seco, Diccionario de dudas y dificultades de la lengua española, 9a ed., 1986], Ínsula, 483, febrero 1987, pág. 3.

278. "El mundo de la antigua lírica popular hispánica" [sobre Margit Frenk, Corpus de la antigua lírica popular hispánica, (siglos XV a XVII)], Saber/Leer, 19, noviembre 1988, págs. 4-5. (Publicado también en De Berceo a Jorge Guillén. Estudios literarios, Madrid, Gredos, 1997, págs. 110-121).

\section{PRÓlOgOS}

279. Prólogo a G. de Granda, Transculturación e interferencia lingüística en el Puerto Rico contemporáneo (1898-1968), Bogotá, Publicaciones del Instituto Caro y Cuervo, XXIV, 1968.

280. Prólogo a María Cruz Seoane, El primer lenguaje constitucional español (las Cortes de Cádiz), Madrid, Moneda y Crédito, 1968

281. Prólogo a D. Ynduráin, Análisis formal de la poesía de Espronceda, Madrid, Taurus, 1971.

282. "La Colección de Textos Singulares de la España Medieval”, prólogo a El diploma del rey Silo, Madrid, Joyas Bibliográficas, 1971, pág. 9.

283. Prólogo al Diccionario Histórico de la Lengua Española, Madrid, Real Academia Española, 1972. (Publicado también en Léxico e Historia. II. Diccionarios, Madrid, Istmo, 1992, págs. 41-61).

284. Prólogo a Francisco Marcos Marín, Aproximación a la gramática española, Madrid, Cincel, 1972.

285. "Sobre el origen de la palabra español", prólogo a Américo Castro, Sobre el nombre y el quién de los españoles, Madrid, Taurus, 1973.

286. Prólogo a Werner Beinhauer, El humorismo en el español contemporáneo, Madrid, Gredos, 1973.

287. Prólogo a Lucrecia Casiano Montáñez, Estudio lingüístico de Caguas, Mayagüez, Universidad de Puerto Rico en Mayagüez, 1973. 
288. Prólogo a Marina Mayoral, La poesía de Rosalía de Castro, Madrid, Gredos, 1974. (Publicado con el título de "Prólogo a un libro sobre Rosalía" en Poetas y prosistas de ayer y de hoy, Madrid, Gredos, 1977, págs. 230-234).

289. Prólogo Juana G[arcía] Campos y Ana Barella, Diccionario de refranes, Madrid, Anejo XXX del BRAE, 1975. (Reproducido en Léxico e historia. II. Diccionarios, Madrid, Istmo, 1992, págs. 87-89).

290. "Prefacio" al Diccionario de la Lengua Española, Buenos Aires-Madrid, Cincel, 1979, págs. 7-8. (Reproducido en Léxico e historia. II. Diccionarios, Madrid, Istmo, 1992, págs. 90-92).

291. Prólogo a Rafael Cano Aguilar, Estructuras sintácticas transitivas en el español actual, Madrid, Gredos, 1981.

292. Prólogo a Alfonso X, Lapidario: según el manuscrito escurialense H.I.15, introducción y notas de Sagrario Rodríguez Martín Montalvo, Madrid, Gredos, 1981.

293. Prólogo a Santos Alonso, Tensión semántica (lenguaje y estilo) de Gracián, Zaragoza, Institución Fernando el Católico, 1981.

294. Prólogo a Carlos Albarracín Sarmiento, Estructura del "Martín Fierro", Amsterdam, John Benjamins, 1981.

295. Prólogo a José María Moreiro, Guiomar, un amor imposible de Antonio Machado, Madrid, Espasa-Calpe, 1982.

296. Prólogo a Rogelio Pérez Bustamante y José Manuel Calderón Ortega, El Marqués de Santillana. Biografía y documentación, Fuentes documentales para la historia de Santilana del Mar, Santillana del Mar, Fundación Santillana, 1983.

297. Prólogo a $\mathrm{M}^{\mathrm{a}}$ Nieves de Paula Pombar, Contribución al estudio de la aposición en español actual, Santiago de Compostela, Universidad de Santiago de Compostela, Verba, Anexo 20, 1983.

298. Prólogo a Álvaro Galmés de Fuentes, Dialectología mozárabe, Madrid, Gredos, 1983.

299. Prólogo a Doris Ruiz Otin, Política y sociedad en el vocabulario de Larra, Madrid, Centro de Estudios Constitucionales, 1984.

300. Estudio preliminar a Alfonso el Sabio, Setenario, edición e introducción de Kenneth H. Vanderford, Barcelona, Crítica, 1984.

301. Prólogo a Isabel Paraíso, El verso libre hispánico. Orígenes y corrientes, Madrid, Gredos, 1985.

302. Prólogo a Francisco Ayala, La retórica del periodismo y otras retóricas, Madrid, Espasa-Calpe, 1985, págs. 9-34. (Reproduce, con alguna corrección, la contestación de R. Lapesa al discurso de entrada en la RAE de F. Ayala).

303. Prólogo a Josefina Pérez Teijón, Contribución al estudio lingüístico del siglo XVIII, Salamanca, Universidad de Salamanca, 1985.

304. Introducción a Vicente García de Diego, Diccionario etimológico español e hispánico, Madrid, Espasa-Calpe, 1985.

305. Prólogo a Salvador Fernández Ramírez, La derivación nominal, Madrid, Anejos del BRAE, XL, 1986. (Reproducido en El español moderno y contemporáneo. Estudios lingüísticos, Barcelona, Crítica, 1996, págs. 174-179).

306. Prólogo a Francisco Abad, Diccionario de lingüística de la Escuela Española, Madrid, Gredos, 1986. 
307. Prólogo a José Ruiz-Castillo Basala, El apasionante mundo del libro, 5a ed., Madrid, Fundación Germán Sánchez Ruipérez, 1986.

308. Prólogo a José Luis Girón Alconchel, Las oraciones interrogativas indirectas en español medieval, Madrid, Gredos, 1988.

309. Prólogo a Félix Sepúlveda Barrios, La voz pasiva en el español del siglo XVII, Madrid, Gredos, 1988.

310. Prólogo a Ramón Menéndez Pidal, Poesía juglaresca y juglares. Orígenes de las literaturas romances, Madrid, Espasa-Calpe, 1991.

311. Prólogo a Ramón Menéndez Pidal, La lengua castellana en el siglo XVII, Madrid, Espasa-Calpe, 1991.

312. Prólogo a Joaquín Pérez Villanueva, Ramón Menéndez. Pidal. Su vida y su tiempo, Madrid, Espasa-Calpe, 1991.

313. Prólogo a Manuel Álvarez Nazario, Historia de la lengua española en Puerto Rico, San Juan, Academia Puertorriqueña de la Lengua Española, 1991.

314. Prólogo a María del Carmen Sanchis Calvo, El lenguaje de la Fazienda de Ultramar, Madrid, Anejos del BRAE, XLIX, 1991.

315. Prólogo a El legado cultural de España al siglo XXI. 2. La literatura: clásicos contemporáneos, Barcelona, Colegio Libre de Eméritos-Círculo de Lectores, 1992.

316. Prólogo a Lope de Vega, El Otomano famoso, o la famosa comedia otomana, edición de Lola Beccaria, Barcelona, Altera, 1996.

317. Prólogo a Glosario del primitivo léxico ibero-románico. Proyecto de informatización. Homenaje a Rafael Lapesa en sus noventa años, 8-II-1998, Madrid, Fundación Ramón Menéndez Pidal y Seminario Menéndez Pidal-Universidad Complutense de Madrid, 1998.

\section{DISCURSOS}

318. Los decires narrativos del Marqués de Santillana. Discurso leído el día 21 de marzo de 1954, en su recepción pública [en la RAE], por el Excmo. Sr. D. Rafael Lapesa Melgar. Contestación del Excmo. Sr. D. Dámaso Alonso. Madrid, Real Academia Española, 1954, págs. 9-97.

319. "Historia lingüística e Historia general", discurso inaugural de la Sección VII del XXIV Congreso Luso-Español para el Progreso de las Ciencias, pronunciado el 14 de noviembre de 1958, Madrid, 1959, Actas del Congreso LusoEspañol para el Progreso de las Ciencias, Madrid, C. Bermejo, 1959, págs. 173-179. (Reproducido en Buscad sus pares, pocos, Madrid, Cátedra-Seminario Menéndez Pidal de la Universidad Complutense de Madrid, Gredos, 1978, págs. 13-24. También en Estudios de morfosintaxis histórica del español, Madrid, Gredos, 2000, págs. 25-31).

320. "El Marqués de Santillana a los 500 años", Conmemoración de tres centenarios. Discursos leídos por los Excmos. señores Don Rafael Lapesa Melgar, Don Gerardo Diego Cendoya y Don José María de Cossío y Martínez-Fortún, Madrid, Magisterio Español, 1959. (Publicado en Buscad sus pares, pocos, 
Madrid, Cátedra-Seminario Menéndez Pidal de la Universidad Complutense de Madrid, Gredos, 1978, págs. 49-62).

321. Palabras pronunciadas en la sesión de clausura del V Congreso de Academias de la Lengua Española (Quito, 1 de agosto de 1968), Cuadernos del Idioma, III, 11, 1969, págs. 181-183. (Publicadas también en la Memoria del V Congreso de Academias de la Lengua Española, Quito, Ed. Ecuatoriana, págs. 301-303. También, con el título de "Palabras de despedida", en El español moderno y contemporáneo. Estudios lingüísticos, Barcelona, Crítica, 1996, págs. 207-210).

322. "La toponimia como herencia histórica y lingüística". Discurso inaugural del coloquio sobre Toponimia cartográfica organizado por la Asociación Española para el Progreso de las Ciencias y celebrado en el CSIC. Publicado en Las Ciencias, XXXIV, 1969, págs. 239-251. (Reproducido en Léxico e historia. I. Palabras, Madrid, Istmo, 1992, págs. 169-189).

323. “Américo Castro. Semblanza de un maestro". Leído el 13 de febrero de 1973 en el Homenaje a Américo Castro organizado por la Asociación Española de Mujeres Universitarias. (Reimpreso en Poetas y prosistas de ayer y de hoy, Madrid, Gredos, 1977, págs. 353-361).

324. "Discurso inaugural", Actas del Sexto Congreso Internacional de Hispanistas celebrado en Toronto del 22 al 26 de agosto de 1977, publicado bajo la dirección de Alan M. Gordon y Evelyn Russ, Toronto, University of Canada, 1980, págs. 1-4.

325. "Sobre los Orígenes de la lengua española de Gregorio Mayans", Lección pronunciada por el profesor Rafael Lapesa en el Acto de Investidura como Doctor Honoris Causa por la Universitat de València (febrero de 1985). (Publicado en Estudios lingüísticos, literarios y estilísticos, Valencia, Universitat de València, 1987, págs. XIII-XX. También en El español moderno y contemporáneo. Estudios lingüísticos, Barcelona, Crítica, 1996, págs. 54-66).

326. Discursos pronunciados en la visita del Excmo. Sr. Don Rafael Hernández Colón, Gobernador del Estado Libre Asociado de Puerto Rico, a la Real Academia Española (16 de mayo de 1988). Palabras de D. Rafael Lapesa Melgar, director interino de la Academia, BRAE, LXVIII, 1988, págs. 349-352.

327. "La lengua española ante el V centenario". Discurso leído el día 13 de junio de 1988 en el Club Siglo XXI ante S.A.R. el Príncipe de Asturias. (Publicado en Cervantina. Acción Cultural Miguel de Cervantes, Barcelona, 10, 1988, págs. 12-13. También en El español moderno y contemporáneo. Estudios lingüísticos, Barcelona, Crítica, 1996, págs. 460-465).

328. Presentación a El español de dos mundos, de Manuel Alvar López, en Ciclo de conferencias de la Real Academia Española pronunciadas en la Fundación Ramón Areces, Madrid, Centro de Estudios Ramón Areces, 1991, págs. 11-14.

329. "La expresión por la palabra". Conferencia dada el 13 de diciembre de 1993 en el ciclo "La decadencia evitable", dirigido por Julián Marías y organizado por Fundes. Publicado con el título de "Rafael Lapesa. La expresión por la palabra [Resumen]", Cuenta y Razón del pensamiento actual, 85, 1994, págs. 110-116. 
330. Crisis históricas y crisis de la lengua española. Discurso leído el día 14 de abril de 1996 en su recepción pública en la Ral Academia de la Historia por el Excmo. Sr. D. Rafael Lapesa Melgar. Contestación por el Excmo. Sr. D. Pedro Laín Entralgo. Madrid, Real Academia de la Historia, 1996, págs. 9-75.

Véase también 92 y 231.

\section{CONTESTACIONES A DISCURSOS}

331. Gili Gaya, S., Imitación y creación en el lenguaje infanti. Discurso leído el día 21 de mayo de 1961 en su recepción pública por el Excmo. Sr. D. S.G.G. y contestación del Excmo. Sr. Don Rafael Lapesa Melgar, Real Academia Española.

332. Marías Aguilera, J., La realidad histórica y social del uso lingüístico. Discurso de recepción del Académico de número Excmo. Sr. D. J.M.A. y contestación del Excmo. Sr. Don Rafael Lapesa Melgar, Real Academia Española, sesión del 20 de junio de 1965. (Reimpresa en Léxico e historia. II. Diccionarios, Madrid, Istmo, 1992, págs. 99-100).

333. Zamora Vicente, A., Asedio a "Luces de Bohemia", primer esperpento de Ramón del Valle Inclán. Discurso leído por el Excmo. Sr. D. A.Z.V. en su recepción en la Real Academia Española, 28 de mayo de 1967. Contestación del Excmo. Sr. Don Rafael Lapesa Melgar.

334. Enrique y Tarancón, V., Liturgia y lengua viva del pueblo. Discurso leído por el Excmo. y Rvmo. Sr. D. V.E.T. en su recepción en la Real Academia Española, 24 de mayo de 1970. Contestación del Excmo. Sr. Don Rafael Lapesa Melgar. (Contestación publicada bajo el título de "Liturgia y lengua viva del pueblo", en Joaquín Ruiz Jiménez (ed.), Iglesia, Estado y Sociedad, Madrid, Argos Vergara, 1984, págs. 348-357).

335. Lázaro Carreter, F., Crónica del Diccionario de Autoridades (1713-1740). Discurso leído por el Excmo. Sr. D. F.L.C. en su recepción en la Real Academia Española, 11 de junio de 1972. Contestación del Excmo. Sr. Don Rafael Lapesa Melgar. (Reimpresa en Léxico e historia. II. Diccionarios, Madrid, Istmo, 1992, págs. 100-103).

336. Seco Reymundo, M, Las palabras en el tiempo: los diccionarios históricos. Discurso leído el día 23 de novimebre de 1980 en su recepción pública [en la Real Academia Española] por el Excmo. Sr. D. M.S.R. Contestación del Excmo. Sr. Don Rafael Lapesa Melgar. (Reimpresa en Léxico e historia. II. Diccionarios, Madrid, Istmo, 1992, págs. 103-107).

337. Lorenzo Criado, E., Utrum lingua an loquentes? (Sobre las presuntas dolencias y carencias de nuestro idioma). Discurso leído el día 22 de noviembre de 1981 en su recepción pública [en la Real Academia Española] por el Excmo. Sr. D. E.L.C. Contestación del Excmo. Sr. Don Rafael Lapesa Melgar. (Reimpresa en Léxico e historia. II. Diccionarios, Madrid, Istmo, 1992, págs. 108-109). 
338. Quiroga y de Abarca, E., Presencia y ausencia de Álvaro Cunqueiro. Discurso leído el día 8 de abril de 1984 en su recepción pública [en la Real Academia Española] por la Excma. Sra. D ${ }^{a}$. E.Q.A. Contestación del Excmo. Sr. Don Rafael Lapesa Melgar. (Contestación reproducida con el título de "Elena Quiroga y sus novelas" en De Ayala a Ayala. Estudios literarios y estilísticos, Madrid, Istmo, 1988, págs. 315-332).

339. Ayala García Duarte, F., La retórica del periodismo. Discurso leído el día 25 de noviembre de 1984 en su recepción pública [en la Real Academia Española] por el Excmo. Sr. D. F.A.G.D. Contestación del Excmo. Sr. Don Rafael Lapesa Melgar. (Contestación reproducida con el título de "Semblanza y obra de Francisco Ayala" en De Ayala a Ayala. Estudios literarios y estilísticos, Madrid, Istmo, 1988, págs. 341-359).

340. Galmés de Fuentes, Á., Toponimia: mito e historia. Discurso leído el día 15 de diciembre de 1996, en su recepción pública [en la Real Academia de la Historia] por el Excmo. Sr. D. A.G.F. Contestación del Excmo. Sr. Don Rafael Lapesa Melgar.

\section{SOBRE AUTORES CONTEMPORÁNEOS}

341. "El magisterio de Dámaso Alonso", Ínsula, XIII, 1958.

342. "Homenaje de la Real Academia Española a su Director, Excmo. Sr. D. Ramón Menéndez Pidal, con ocasión de cumplir éste los noventa años", BRAE, XXXIX, 1959, págs. 21-25.

343. "Nuestra deuda con don Ramón", $A B C, 14$ de mayo de 1959.

344. "Doctrina y ejemplo de don Ramón", Papeles de Son Armadans, IV, tomo XIII, 1959, págs. 311-318.

345. "Una cuartilla sobre Américo Castro", Papeles de Son Armadans, CX, 1965, págs. 125-127.

346. "La Facultad de Filosofía y Letras de Madrid durante el decanato de García Morente", La Universidad, Madrid, Ciencia Nueva, 1969, págs. 33-38.

347. “Carta abierta al P. Sopeña”, Cuadernos para el Diálogo, 85, 1970, pág. 13.

348. "Dámaso Alonso, humano maestro de Humanidades", Homenaje universitario a Dámaso Alonso, reunido por los estudiantes de Filología Románica, curso 1968-1969, Madrid, Gredos, 1970, págs. 9-17. (Reimpreso en Poetas y prosistas de ayer y de hoy, Madrid, Gredos, 1977, págs. 370-384).

349. "La obra lingüística de Don Miguel Asín”, BRAE, LI, 1971, págs. 393-401. (Publicado también con el título de "Don Miguel Asín, lingüista", en AlAndalus, XXXIX, 1969 [1972], págs. 541-460. También, con el título de "Don Miguel Asín y Palacios (1871-1944)", en Generaciones y semblanzas de claros varones y gentiles damas que ilustraron la Filología hispánica de nuestro siglo, Madrid, Real Academia de la Historia, 1998, págs. 51-62).

350. “Alonso Zamora, hombre y narrador", Papeles de Son Armadans, LXX, 1973, págs. 329-336. (Reimpreso en Poetas y prosistas de ayer y de hoy, Madrid, Gredos, 1977, págs. 415-421). 
351. Don Samuel Gili Gaya: semblanza y obra, Lérida, Instituto de Estudios Ilerdenses, 1977.

352. “Dámaso y su Dios”, Homenaje a Dámaso Alonso, Madrid, Club Urbis, 1978, págs. 98-99.

353. "Ramón Menéndez Pidal”, Dizionario Enciclopedico UNEDI, vol 9, 1978, pág. 211.

354. "Marcel Bataillon, hispaniste", Les cultures ibériques en devenir. Essais en hommage à la mémoire de Marcel Bataillon (1895-1977). Paris, Fondation Singer-Polignac, 1979, págs. 39-45.

355. "Menéndez Pidal, creador de escuela: el Centro de Estudios Históricos", jAlça la voz, pregonero! Homenaje a Don Ramón Menéndez Pidal, organizado por la Corporación de antiguos alumnos de la Institución Libre de Enseñanza; publicado con la cooperación de la Cátedra-Seminario Menéndez Pidal, Universidad Complutense, Madrid, 1979, págs. 43-79.

356. "Una mente equilibrada y clara", en Pedro Caravia Hevia, Sobre arte y poesía, Oviedo, Caja de Ahorros de Asturias, 1982, pág. 27.

357. "Contextos: Menéndez Pidal y el Centro de Estudios Históricos", Historia y crítica de la literatura española. VII. Época contemporánea (1914-1939), Barcelona, Crítica, 1984, págs. 71-79.

358. "Un catedrático ejemplar", Centenario de Américo Castro, $A B C, 4$ de mayo de 1985, págs. 8-9.

359. "Américo Castro: las glorias y el dolor de España", Ya, Madrid, 4 de mayo de 1985, Cultura, págs, 19-20.

360. "Filólogo y crítico literario" [sobre Dámaso Alonso], $A B C, 28$ de septiembre de 1985, "Sábado cultural", págs. 6-7.

361. "Recuerdo y lección sobre el plan Morente", Revista de Occidente, 60, 1986, págs. $78-88$.

362. "Nuestra deuda con Enrique Canito", Ínsula, 480, noviembre de 1986, pág. 5. (Reimpreso en Generaciones y semblanzas de claros varones y gentiles damas que ilustraron la Filología hispánica de nuestro siglo, Madrid, Real Academia de la Historia, 1998, págs. 201-202).

363. "Semblanza de Américo Castro", en Joseph H. Silverman y J. Jesús Bustos Tovar (coords.), Homenaje a Américo Castro, Madrid, Universidad Complutense de Madrid, 1987, págs. 121-134. (Reimpreso, con el título de "Semblanza complementaria de Américo Castro", en De Berceo a Jorge Guillén. Estudios literarios, Madrid, Gredos, 1997, págs. 238-255. También con el título de "Don Américo Castro Quesada (1885-1972)", en Generaciones y semblanzas de claros varones y gentiles damas que ilustraron la Filología hispánica de nuestro siglo, Madrid, Real Academia de la Historia, 1998, págs. 93-113).

364. "Marañón en la literatura española", Cuenta y Razón del pensamiento actual, junio-julio 1987, págs. 39-50. (Publicado también en De Berceo a Jorge Guillén. Estudios literarios, Madrid, Gredos, 1997, págs. 256-274).

365. "Biografía científica de Álvaro Galmés de Fuentes", Homenaje a Álvaro Galmés de Fuentes, III, Madrid, Gredos, 1987, págs. 9-18. 
366. "La huella de Américo Castro en los estudios de lingüística española", en Ronald E. Surtz, Jaime Ferrán y Daniel P. Testa (eds.), Américo Castro: the Impact of his thougth. Essays to Mark the Centenary of his Birth, Madison (Wisconsin), Hispanic Seminary of Medieval Studies, 1988, págs. 97-113.

367. “Cómo enseñaba a trabajar don Ramón: sus obras y materiales inéditos", BRAE, LXVIII, 245, 1988, págs. 398-402.

368. "Recuerdos de mi amistad con Dámaso Alonso", Dámaso Alonso. In memoriam, Madrid, Universidad Complutense de Madrid, 1991, págs. 17-28. (Reimpreso en Generaciones y semblanzas de claros varones y gentiles damas que ilustraron la Filología hispánica de nuestro siglo, Madrid, Real Academia de la Historia, 1998, págs. 173-182).

369. "El Cardenal Tarancón i la Real Academia Española”, SAO, XVI, maig, 1991, págs. 53-54.

370. "Palabras introductorias al III homenaje tributado a Hans Flasche", Homenaje a Hans Flasche. Festschrift zum 80 Geburstag. Stuttgart, Franz Steiner, 1991, págs. 11-12.

371. "Pedro Salinas en mi recuerdo", Boletín de la Institución Libre de Enseñanza, 13, 1992, págs. 9-12. (Reimpreso, con el título de "Don Pedro Salinas (18921951), en Generaciones y semblanzas de claros varones y gentiles damas que ilustraron la Filología hispánica de nuestro siglo, Madrid, Real Academia de la Historia, 1998, págs. 123-128).

372. "Ramón Menéndez Pidal", El legado cultural de España al siglo XXI. 1. Pensamiento, Historia y Ciencia, Barcelona, Colegio Libre de Eméritos-Círculo de Lectores, 1992, págs. 16-41.

373. "Amado Alonso", El legado cultural de España al siglo XXI. 2. La literatura: clásicos contemporáneos, Barcelona, Colegio Libre de Eméritos-Círculo de Lectores, 1992, págs. 327-337.

374. "Dámaso Alonso", El legado cultural de España al siglo XXI. 2. La literatura: clásicos contemporáneos, Barcelona, Colegio Libre de Eméritos-Círculo de Lectores, 1992, págs. 295-320.

375. "Mi recuerdo de Amado Alonso", Hispanica Helvetica, 4, Estudios de literatura y lingüística españolas: miscelánea en honor de Luis López Molina, [Lausanne], Sociedad Suiza de Estudios Hispánicos, 1992, págs. 321-334. (Reimpreso, con el título de "Don Amado Alonso (1896-1952), en Generaciones y semblanzas de claros varones y gentiles damas que ilustraron la Filología hispánica de nuestro siglo, Madrid, Real Academia de la Historia, 1998, págs. 153-171).

376. "Homenaje a Justina Ruiz de Conde, Adiós a la Asociación Española de Mujeres Universitarias (1992)", Homenaje a Justina Ruiz de Conde en sus ochenta cumpleaños, Erie, Pennsylvania, ALDEEU, 1992, págs. 127-128. (Reimpreso en Generaciones y semblanzas de claros varones y gentiles damas que ilustraron la Filología hispánica de nuestro siglo, Madrid, Real Academia de la Historia, 1998, págs. 219-221).

377. "Mi recuerdo de Enrique Canito", Ínsula, 554-555, febrero-marzo de 1993.

378. "Mi recuerdo de Jorge Guillén", Revista de Occidente, 144 mayo, 1993, págs. 49-55. (Reimpreso, con el título de "Don Jorge Guillén (1893-1993), en 
Generaciones y semblanzas de claros varones y gentiles damas que ilustraron la Filología hispánica de nuestro siglo, Madrid, Real Academia de la Historia, 1998, págs. 129-135).

379. "Mi recuerdo de Dámaso Alonso", BRAE, LXXIII, 259, Homenaje a Don Dámaso Alonso, 1993, págs. 243-250.

380. "Recuerdos de mi relación personal con Antonio Machado (1932-1936)", Antonio Machado hoy (1939-1989). Coloquio Internacional organizado por la Fundación Antonio Machado y la Casa de Velázquez. Madrid, 11, 12 y 13 de mayo de 1989, Madrid, Casa de Velázquez, 1994, págs. 245-248. (Reimpreso con el título de "Don Antonio Machado (1875-1939)" en Generaciones y semblanzas de claros varones y gentiles damas que ilustraron la Filología hispánica de nuestro siglo, Madrid, Real Academia de la Historia, 1998, págs. 79-86).

381. “Amado Alonso", Ínsula, 599, 1996, págs. 1-2.

382. "Recuerdo y legado de Amado Alonso", Lexis. Revista de lingüística y literatura, 20, 1-2, 1996, págs. 11-30.

383. “Juan Fernández Montesinos (1897-1972)”, Generaciones y semblanzas de claros varones y gentiles damas que ilustraron la Filología hispánica de nuestro siglo, Madrid, Real Academia de la Historia, 1998, pág. 183).

384. "Margot Arce de Vázquez (1904-?)", Generaciones y semblanzas de claros varones y gentiles damas que ilustraron la Filología hispánica de nuestro siglo, Madrid, Real Academia de la Historia, 1998, pág. 199).

385. "María Rosa Lida de Malkiel (1910-1962)", Generaciones y semblanzas de claros varones y gentiles damas que ilustraron la Filología hispánica de nuestro siglo, Madrid, Real Academia de la Historia, 1998, pág. 217).

386. "María Josefa Canellada de Zamora (1912-1995)", Generaciones y semblanzas de claros varones y gentiles damas que ilustraron la Filología hispánica de nuestro siglo, Madrid, Real Academia de la Historia, 1998, pág. 239).

387. "Carmen Castro Madinaveitia de Zubiri (1912-1997)", Generaciones y semblanzas de claros varones y gentiles damas que ilustraron la Filología hispánica de nuestro siglo, Madrid, Real Academia de la Historia, 1998, págs. 241-242).

388. "Pilar Lago Couceiro de Lapesa (1900-1984)", Generaciones y semblanzas de claros varones y gentiles damas que ilustraron la Filología hispánica de nuestro siglo, Madrid, Real Academia de la Historia, 1998, págs. 243-245).

389. Generaciones y semblanzas de claros varones y gentiles damas que ilustraron la Filología hispánica de nuestro siglo, Madrid, Real Academia de la Historia, 1998, 250 págs. (Contiene los trabajos 349, 362, 363, 368, 371, 375, $376,378,380,383,384,385,386,387,388,392,393,394,398,399,400$, 401, 403, 404, 405 у 411).

Véase también 155, 312, 323 y 414.

\section{NECROLÓGICAS}

390. “Amado Alonso. Su última lección”, Clavileño, 15, 1952, pág. 52.

391. “Amado Alonso (1896-1952)”, Hispania, XXXVI, 1953, págs. 145-147. 
392. "Don Julio Casares (1877-1964)”, BRAE, XLIV, 1964, págs. 213-221. (Reimpreso en Generaciones y semblanzas de claros varones y gentiles damas que ilustraron la Filología hispánica de nuestro siglo, Madrid, Real Academia de la Historia, 1998, págs. 63-62).

393. "Manuel García Blanco", Cuadernos de la Cátedra Miguel de Unamuno, XVIXVII, 1967, págs. 15-19. (Reimpreso en Generaciones y semblanzas de claros varones y gentiles damas que ilustraron la Filología hispánica de nuestro siglo, Madrid, Real Academia de la Historia, 1998, págs. 191-198).

394. "Don Ramón Menéndez Pidal. Los trabajos y los días", Razón y Fe, CLXXIX, 1969, págs. 475-492. (Reimpreso en Generaciones y semblanzas de claros varones y gentiles damas que ilustraron la Filología hispánica de nuestro siglo, Madrid, Real Academia de la Historia, 1998, págs. 11-36).

395. "La mesura del claro varón”, BRAE, XLIX, 1969, págs. 391-394.

396. "Menéndez Pidal y la lingüística", Cuadernos Hispanoamericanos, LXXX, 238240, 1969, págs. 7-16.

397. "Don Ramón Menéndez Pidal. Ejemplo y doctrina”, Filología, XIII, 1968-1969 [1970], págs. 1-32.

398. “Don Manuel Gómez Moreno”, BRAE, L, 1970, págs. 397-409. (Reimpreso en Generaciones y semblanzas de claros varones y gentiles damas que ilustraron la Filología hispánica de nuestro siglo, Madrid, Real Academia de la Historia, 1998, págs. 37-50).

399. “Carlos Clavería (1909-1974)”, BRAE, LIV, 1974, págs. 357-363. (Reimpreso con el título de "Carlos Clavería Lizana (1909-1974)" en Generaciones y semblanzas de claros varones y gentiles damas que ilustraron la Filología hispánica de nuestro siglo, Madrid, Real Academia de la Historia, 1998, págs. 209-216).

400. “Samuel Gili Gaya (1892-1976)”, BRAE, LVI, 1976, págs. 195-202. (También en Boletín de la Comisión Permanente de la Asociación de Academias de la Lengua Española, 24, julio-diciembre 1976 págs. 45-51. (Reimpreso en Generaciones y semblanzas de claros varones y gentiles damas que ilustraron la Filología hispánica de nuestro siglo, Madrid, Real Academia de la Historia, 1998, págs. 115-122).

401. "Enrique Moreno Báez (1908-1976)”, Ínsula, 364, marzo 1977. (Reimpreso en Generaciones y semblanzas de claros varones y gentiles damas que ilustraron la Filología hispánica de nuestro siglo, Madrid, Real Academia de la Historia, 1998, págs. 203-208).

402. "Recuerdo y semblanza de Marcel Bataillon", Ínsula, 372, noviembre 1977.

403. "Don Vicente García de Diego, maestro", BRAE, LIX, 1979, págs. 7-11. (Reimpreso con el título de "Don Vicente García de Diego (1878-1978)" en Generaciones y semblanzas de claros varones y gentiles damas que ilustraron la Filología hispánica de nuestro siglo, Madrid, Real Academia de la Historia, 1998, págs. 73-78).

404. "Navarro Tomás. Vida y obra de un noble varón”, Ínsula, XXXIV, 395, octubre 1979, pág. 3. (Reimpreso con el título de "Don Tomás Navarro Tomás (1884-1979)" en Generaciones y semblanzas de claros varones y gentiles 
damas que ilustraron la Filología hispánica de nuestro siglo, Madrid, Real Academia de la Historia, 1998, págs. 87-92).

405. "Salvador Fernández Ramírez (1897-1983)”, BRAE, LXIII, 1983, 15-28. (Reimpreso en Generaciones y semblanzas de claros varones y gentiles damas que ilustraron la Filología hispánica de nuestro siglo, Madrid, Real Academia de la Historia, 1998, págs. 137-152).

406. "Enrique Lafuente Ferrari, historiador humanista del arte", $Y a, 28$ de octubre de 1985.

407. "Stephen Gilman, modelo de hispanistas", $A B C, 6$ de diciembre de 1986.

408. "Una vida heroica" [José Antonio Maravall], $A B C, 21$ de diciembre de 1986.

409. "Ramón Areces, protector de las humanidades", $A B C, 4$ de agosto de 1989.

410. "Dámaso Alonso (1898-1990)", BRAE, LXX, 249, 1990, págs. 17-39.

411. "Homenaje a Jimena Menéndez Pidal (1901-1990)", Boletín de la Institución Libre de Enseñanza, 10, 1990, págs. 93-95. (Reimpreso en Generaciones y semblanzas de claros varones y gentiles damas que ilustraron la Filología hispánica de nuestro siglo, Madrid, Real Academia de la Historia, 1998, págs. 185-189).

412. “Cardenal don Vicente Enrique y Tarancón (1907-1994)”, BRAE, LXXIV, 263, 1994, págs. 437-453.

413. "Emilio García Gómez", BRAE, LXXVI, 267, 1996, págs. 7-20.

414. "Joan Corominas. Un catalán en mi recuerdo", El País, 3 de enero de 1997. (Reimpreso en Boletín de la Fundación Federico García Lorca, 33-34, 2003, págs. 317-318).

Véase también 323.

XXIV. OTROS

415. "Loa en honor de Nebrija”, El eco de Alcalá, 21 de mayo de 1922.

416. Programa de Historia general de la literatura. Curso 1932-1933, Madrid, Instituto de segunda enseñanza "Calderón de la Barca".

417. [Respuesta a] Literatura y Educación. Encuesta realizada por Fernando Lázaro Carreter, Madrid, Castalia, 1974, págs. 91-95.

418. Rafael Lapesa (coord.), Comunicación y Lenguaje, Instituto de Ciencias del Hombre, Madrid, Karpos, 1976.

419. Buscad sus pares, pocos, publicado por la "Cátedra-Seminario Menéndez Pidal", de la Universidad Complutense de Madrid, Madrid, Gredos, 1978. (Contiene los trabajos 58, 319 y 320).

420. Mensaje del Excmo. Sr. D. Rafael Lapes Melgar, Catedrático de la Facultad de Filosofía y Letras de la Universidad Complutense, y Académico Numerario de la Real Acedemia Española de la Lengua, en Homenaje al Ilmo. Sr. D. Ignacio Aguilera y Santiago, [1977], I, Santander, Institución Cultural de Cantabria, I, 1981, págs. 369-370.

421. Rafael Lapesa et al., Terminología gramatical para su empleo en la Educación General Básica, Madrid, Subdirección General de Ordenación Educativa, 1981. 
422. "El libro como instrumento de unidad lingüística", La cultura del libro, Madrid, Fundación Germán Sánchez Ruipérez-Ediciones Pirámide, 1983, págs. 145-153.

423. "Comunidad lingüística y diversidad nacional en la cultura hispánica: Comentario a las conferencias de los profesores Pinillos y Pajarón", Actas del Simposio sobre posibilidades y límites de una historiografía nacional (Madrid, 812 de marzo de 1983), bajo los auspicios del Instituto Germano-Español de Investigación Goerres Gellschaft, Madrid, ICYT, 1984, págs. 525-553.

424. "Rafael Lapesa cuenta al Boletín sus vivencias y proyectos. Una vida entera dedicada a la investigación y a la docencia". [Entrevista con Magdalena Velasco Kindelán], Boletín del Ilustre Colegio Oficial de Doctoresy Licenciados en Filosofía y Letras, marzo-abril, 1985, págs. 24-25.

425. "Rafael Lapesa: 'Sustituir la religión por la técnica lleva a la catástrofe"” [Entrevista con Santiago Martín, en la serie "Esta es nuestra fe"], $A B C, 21$ de diciembre de 1986, pág. 53.

426. Estudios lingüísticos, literarios y estilísticos, Valencia, Universitat de València, 1987, 154 págs. (Contiene los trabajos 37, 58, 60, 61, 171, 191, 203, 218 y 325 ).

427. [Encuesta sobre el estado actual de la enseñanza en España] "La educación", Cuenta y Razón del pensamiento actual, mayo 1987, págs. 114-115.

428. "La Real Academia Española: pasado, realidad, presente y sentido", BRAE, LXVII, 242, 1987, págs. 327-346. (Reproducido en El español moderno y contemporáneo. Estudios lingüísticos, Barcelona, Crítica, 1996, págs. 221-237).

429. “Acción de gracias" [por el Homenaje a Rafael Lapesa], BRAE, LXVIII, eneroabril 1988, págs. 55-60.

430. [Entrevista realizada por Pedro Sorella al Sr. Don Rafael Lapesa Melgar], El País, 7 de julio de 1988.

431. “Para qué estudiar español? Estado actual de los estudios hispánicos en el mundo", Le manifeste de Madrid. Langues étrangères et communication européenne [El manifiesto de Madrid. Lenguas extranjeras y comunicación europea]. Résultats de la Cinquième Conférence Européenne à Madrid, 17 au 20 juin 1987. Stuttgart, Robert Bosch Stiftung; Fondation Européenne de la Culture, 1989, págs. 77-80.

432. "La responsabilidad de los intelectuales ante la lengua", Cuenta y Razón del pensamiento actual, 48-49, julio-agosto de 1989, págs. 19-28. (Reproducido en El español moderno y contemporáneo. Estudios lingüísticos, Barcelona, Crítica, 1996, págs. 469-482).

433. "Historia de la lengua e historia de la literatura", Historia de la literatura española, I, Madrid, UTET y Cátedra, 1990, págs. 35-75. (Publicado dos meses antes en italiano, con el título de "Storia della lingua e storia della letteratura", en Franco Meregalli (dir.), Storia della civiltà letteraria spagnola, Torino, UTET, 1990, págs. 11-19).

434. "El idioma español en las agencias de prensa" o "Palabras inaugurales", en Pedro García Domínguez y Alberto Gómez Font (comp.), El idioma español en las agencias de prensa, Madrid, Fundación Germán Sánchez Ruipérez, 1990, págs. 18-22. 
435. "Palabras de respuesta y agradecimiento", Premio Amado Alonso. II. 1988. Homenaje a Don Rafael Lapesa Melgar, Buenos Aires, Ministerio de Cultura y Educación, 1991, págs. 29-36.

436. "Mi experiencia en la enseñanza del español y su literatura", Actas del I Congreso Internacional sobre la enseñanza del español, Madrid, Centro Madrileño de Investigaciones Pedagógicas, 1993, págs. 13-22 (Reproducido en Moenia. Revista lucense de lingüística y literatura, 2, 1996, págs. 5-12. También en El español moderno y contemporáneo. Estudios lingüísticos, Barcelona, Crítica, 1996, págs. 483-492).

437. "Javier Mariátegui pregunta. Contesta Rafael Lapesa de la Real Academia Española", La moda en España, 50, 544, 1994, págs. 6-7.

438. "Palabras de Rafael Lapesa", Boletín de la Institución Libre de Enseñanza, 4041, Homenaje a Rafael Lapesa, febrero 2001.

439. "Rafael Lapesa, memoria viva de la lengua española". Entrevista de Milagros Juárez a D. Rafael Lapesa, Sesenta y más, 120, 1995, págs. 12-17.

\section{INÉDITOS}

440. Pero López de Ayala, Rimado de palacio.

441. Glosario del primitivo léxico ibérico-románico, continuación del Léxico Primitivo Hispánico.

442. "De la lengua española clásica a la actual", conferencia grabada en vídeo para ser emitida por televisón por el Colegio Libre de Eméritos de Madrid.

443. "El español de España y de América", conferencia grabada en vídeo para ser emitida por televisón por el Colegio Libre de Eméritos de Madrid.

444. "De cómo el castellano pasó a ser la lengua española", conferencia grabada en vídeo para ser emitida por televisón por el Colegio Libre de Eméritos de Madrid.

445. "La poesía juvenil de Juan Ramón Jiménez”, conferencia grabada en vídeo para ser emitida por televisón por el Colegio Libre de Eméritos de Madrid.

446. "La poesía desnuda y el ansia de eternidad en Juan Ramón", conferencia grabada en vídeo para ser emitida por televisón por el Colegio Libre de Eméritos de Madrid.

447. "El último Juan Ramón”, conferencia grabada en vídeo para ser emitida por televisión por el Colegio Libre de Eméritos de Madrid.

[Los vídeos de estas conferencias pueden verse en la web del C.L.E.: http:// www.colegiodeemeritos.es/Videoteca/seccion=35\&idioma=es_ES.do]

448. Participación radiofónica de D. Rafael Lapesa Melgar: “¿Castellano o Español?", Radio Nacional de España, 9 de noviembre de 1980.

449. Participación radiofónica en el programa "Encuentros en el 92. V Centenario". Radio Nacional de España. Radio Exterior, 2 de junio de 1989.

450. Encuesta radiofónica a D. Rafael Lapesa Melgar, Radio Nacional de España, 31 de julio de 1989. 